Article

\title{
Co-Digestion of Napier Grass and Its Silage with Cow Dung for Methane Production
}

\author{
Wipa Prapinagsorn ${ }^{1,2}$, Sureewan Sittijunda ${ }^{3}$ and Alissara Reungsang $1,4, *$ (D) \\ 1 Department of Biotechnology, Faculty of Technology, Khon Kaen University, Khon Kaen 40002, Thailand; \\ wipa.p@hotmail.com \\ 2 Faculty of Agriculture, Uttaradit Rajabhat University, Uttaradit 53000, Thailand \\ 3 Faculty of Environment and Resource Studies, Mahidol University, Nakhon Pathom 73170, Thailand; \\ sureewan.sit@mahidol.ac.th or sittijunda27@gmail.com \\ 4 Research Group for Development of Microbial Hydrogen Production Process from Biomass-Khon Kaen \\ University, Khon Kaen 40002, Thailand \\ * Correspondence: alissara@kku.ac.th; Tel./Fax: +66-43-362-121
}

Received: 7 August 2017; Accepted: 17 October 2017; Published: 19 October 2017

\begin{abstract}
Methane production from co-digestion of grass with cow dung and silage with cow dung was conducted by a bioaugmentation technique. For self-fermentation, maximum methane yield (MY) of 176.66 and $184.94 \mathrm{~mL} \mathrm{CH}_{4} / \mathrm{g}-\mathrm{VS}_{\text {added }}$ were achieved at a ratio of grass to cow dung and silage to cow dung of 1:1, respectively. A higher maximum MY of 179.59 and $208.11 \mathrm{~mL} \mathrm{CH}_{4} / \mathrm{g}-\mathrm{VS}_{\text {added }}$ was obtained from co-digestion of grass with cow dung and silage with cow dung bioaugmented with anaerobic sludge at a ratio of 3:1. The solid residue left over after co-digestion at a ratio of 3:1 was pretreated by alkaline plus enzyme before used to produce methane and a maximum MY of 333.63 and $301.38 \mathrm{~mL} \mathrm{CH}_{4} / \mathrm{g}-\mathrm{VS}_{\text {added }}$, respectively, was achieved. Overall power generated from co-digestion of grass with cow dung plus pretreated solid residues and co-digestion of silage with cow dung plus pretreated solid residues were 0.0397 and 0.007 watt, respectively.
\end{abstract}

Keywords: energy crop; renewable energy; animal manure; bioaugmentation; biogas

\section{Introduction}

Anaerobic digestion (AD) is a biological process by which organic substrates are degraded and converted to methane $\left(\mathrm{CH}_{4}\right)$ under an anaerobic conditions. The AD process is divided into four phases, namely hydrolysis, acidogenesis, acetogenesis, and methanogenesis [1]. Hydrolysis is generally a critical step for the initiation of $\mathrm{AD}$ that results in a low methane production when complex substrates such as lignocellulosic materials are used as feedstocks. To resolve this problem, bioaugmentation with an inoculum capable of efficiently producing methane has been conducted. A previous report by Moset et al. [2] found that various inoculum sources such as from animal manure and sludge municipal wastewater treatment plant enhanced the biodegradability and the methane production rate or hydrolysis rate in comparison to without inoculum addition. Saravanane et al. [3] reported that an addition of pure or enriched cultures increased the degradation rate and gas yield during decomposition of contaminated wastewater. An addition of pure hydrolytic bacteria such as Pseudobutyrivibrio xylanivorans Mz5 was found to enhance methane production from brewery spent grain [4]. Not only pure cultures but also co-cultures and mixed cultures were reported to enhance the efficiency of biogas production. For example, Cater et al. [4] reported a successful use of co-cultures of Pseudobutyrivibrio xylanivorans Mz5 (T) and Fibrobacter succinogenes $\mathrm{S} 85$ and co-culture of Clostridium cellulovorans and Fibrobacter succinogenes $\mathrm{S} 85$ for methane production from brewery spent grain. In addition, the use of mixed cultures such as sewage sludge [5], anaerobic digested sludge [6], upflow anaerobic sludge blanket (UASB) granules [7] and activated sludge [8,9] were found to enhance 
biogas production. Based on this information, an addition of inocula or bioaugmentation technique is a promising approach to enhance the $\mathrm{AD}$ process. Bioaugmentation of pure cultures has some limitations, including the potential inability to compete with the indigenous microorganisms and a low survival rate in the environment. In contrast, bioaugmentation with the mixed cultures has shown synergistic interactions among microbial consortia and the production of metabolic products such as acetic acid and hydrogen have a positive effect on a methane production. Additionally, mixed cultures have lower requirements for controlled environmental conditions than pure cultures. Hence, bioaugmentation with mixed cultures is a more promising approach.

Napier grass or elephant grass (Pennisetum purpureum) is considered as a new alternative energy crop suitable for biofuel production $[10,11]$. Its annual biomass production is approximately 87 ton/ha [12]. Due to its short agricultural cycle, the grass can be harvested five to six times per year [13]. Oversupply of grass can be used as silage by naturally fermenting the grass under anaerobic conditions [14]. The major components of grass and silage are cellulose and hemicellulose [15]. The cellulose content in grass was reported to be in a range of $35-50 \%$ [13]. Cellulose could be hydrolysed to glucose while hydrolysis of hemicellulose yields xylose, arabinose, glucose, mannose and galactose $[16,17]$. These sugars can be used as carbon sources for methane production. However, grass has a high carbon content (41.6\%) but low nitrogen content ( $0.43 \%)$ [18]. This high carbon to nitrogen ratio is considered unsuitable for AD. Mital [19] and Chandra et al. [1] have reported that a carbon to nitrogen ratio ranging from 20 to 30 is considered optimum for AD processes. In order to prepare a suitable carbon to nitrogen ratio for $\mathrm{AD}$, co-digestion of grass or silage with a high nitrogen content resource such as animal manure is proposed. Co-digestion is found to stabilize the anaerobic process. Waste rich protein such as manure can provide the buffering capacity and richness of necessary nutrients, while waste with high carbon content such as lignocellulose can balance the $\mathrm{C} / \mathrm{N}$ ratio $[20,21]$. For example, $\mathrm{Li}$ [22] reported a successful use of co-digestion of horse manure and grass for methane production. In addition, Wall et al. [23] reported that co-digestion of silage and dairy slurry yielded a highest specific MY of $349 \mathrm{~L} \mathrm{CH}_{4} / \mathrm{kg}$-volatile solid (VS).

At the end of a co-digestion process by AD, methane is recovered as a major product in the gas phase. The volatile fatty acid (VFAs) in the liquid phase and solid residues left over after methane production process can still be a possible resource for further methane production. However, the solid residues require pretreatment to destroy the lignin structure, decrease the amount of crystalline cellulose and increase the cellulose surface area, which leads to a better accessibility of enzymes from fungi or bacteria [24] to hydrolyze cellulose and hemicellulose into fermentable sugars $[17,25]$. Pretreatment methods comprise the physical pretreatment (e.g., milling or grinding), chemical pretreatment (e.g., acid or alkali or ionic liquid) and physicochemical pretreatment (e.g., steam explosion). In this study, different pretreatment methods include physical, chemical, biological and combined pretreatments were used to attain the monosaccharides in the solid residue left over after methane production prior to usage to produce methane.

The objective of this research was to investigate the efficiency of methane production from a co-digestion of grass with cow dung and silage with cow dung by a bioaugmentation technique in comparison to self-fermentation. Moreover, the solid residues left over after the methane production process were subjected to different pretreatment methods before use as a substrate to produce methane in order to recover the total energy from grass and silage.

\section{Results and Discussion}

\subsection{Co-Digestion of Grass with Cow Dung and Silage with Cow Dung for Methane Production by Self-Fermentation}

The experimental set ups for methane production from a co-digestion of grass with cow dung and silage with cow dung by self-fermentation (without anaerobic sludge) and bioaugmentation are tabulated in Table 1. Methane content, and MY by self-fermentation of co-digestion of grass with cow dung and silage with cow dung at various mixing ratios are shown in Table 2. Methane content in all 
experiments ranged from $64-72 \%$ and $62-70 \%$ from co-digestion of grass with cow dung and silage with cow dung, respectively. Methane production (MP) and lag phase increased with an increase of mixing ratio greater than 1:1 (Table 2). In contrast, MY decreased when the mixing ratio increased. Similar trends were observed for both grass with cow dung and silage with cow dung. Maximum MY of 176.66 and $184.94 \mathrm{~mL} \mathrm{CH}_{4} / \mathrm{g}-\mathrm{VS}_{\text {added }}$, from co-digestion of grass with cow dung as well as silage with cow dung, respectively, were obtained at a mixing ratio of 1:1.

Table 1. Experimental set up for methane production from a co-digestion of grass with cow dung and silage with cow dung bioaugmended with anaerobic sludge and a self-fermentation (without anaerobic sludge), using $10 \mathrm{~g}$-VS/L cow dung concentration.

\begin{tabular}{|c|c|c|c|c|c|c|}
\hline $\begin{array}{l}\text { Experimental } \\
\text { Code }\end{array}$ & $\begin{array}{c}\text { Grass } \\
(\mathrm{g}-\mathrm{VS} / \mathrm{L})\end{array}$ & $\begin{array}{l}\text { Silage } \\
(\mathrm{g}-\mathrm{VS} / \mathrm{L})\end{array}$ & $\begin{array}{l}\text { Cow Dung } \\
\text { (g-VS/L) }\end{array}$ & $\begin{array}{c}\text { Grass/Silage to Cow } \\
\text { Dung Ratio (g-VS/g-VS) }\end{array}$ & $\begin{array}{c}\text { Anaerobic Sludge } \\
\text { (g-VS/L) }\end{array}$ & $\begin{array}{l}\text { C/N } \\
\text { Ratio }\end{array}$ \\
\hline \multicolumn{7}{|c|}{ Self-fermentation } \\
\hline $\mathrm{G} / \mathrm{C} 1$ & 10 & - & 10 & 1:1 & - & 31.30 \\
\hline G/C2 & 20 & - & 10 & $2: 1$ & - & 37.19 \\
\hline G/C3 & 30 & - & 10 & $3: 1$ & - & 40.96 \\
\hline G/C4 & 40 & - & 10 & $4: 1$ & - & 43.51 \\
\hline G/C5 & 50 & - & 10 & $5: 1$ & - & 45.51 \\
\hline $\mathrm{G} / \mathrm{C} 6$ & 60 & - & 10 & $6: 1$ & - & 46.99 \\
\hline $\mathrm{S} / \mathrm{C} 1$ & - & 10 & 10 & $1: 1$ & - & 28.83 \\
\hline $\mathrm{S} / \mathrm{C} 2$ & - & 20 & 10 & $2: 1$ & - & 33.09 \\
\hline S/C3 & - & 30 & 10 & $3: 1$ & - & 35.73 \\
\hline S/C4 & - & 40 & 10 & $4: 1$ & - & 37.52 \\
\hline S/C5 & - & 50 & 10 & $5: 1$ & - & 38.82 \\
\hline S/C6 & - & 60 & 10 & $6: 1$ & - & 39.80 \\
\hline \multicolumn{7}{|c|}{ Bioaugmentation } \\
\hline G/C10 & 10 & - & 10 & 1:1 & 10 & 31.30 \\
\hline G/C11 & 20 & - & 10 & $2: 1$ & 10 & 37.19 \\
\hline G/C12 & 30 & - & 10 & $3: 1$ & 10 & 40.96 \\
\hline G/C13 & 40 & - & 10 & $4: 1$ & 10 & 43.51 \\
\hline $\mathrm{G} / \mathrm{C} 14$ & 50 & - & 10 & $5: 1$ & 10 & 45.51 \\
\hline $\mathrm{G} / \mathrm{C} 15$ & 60 & - & 10 & $6: 1$ & 10 & 46.99 \\
\hline S/C10 & - & 10 & 10 & $1: 1$ & 10 & 28.83 \\
\hline $\mathrm{S} / \mathrm{C} 11$ & - & 20 & 10 & $2: 1$ & 10 & 33.09 \\
\hline S/C12 & - & 30 & 10 & $3: 1$ & 10 & 35.73 \\
\hline $\mathrm{S} / \mathrm{C} 13$ & - & 40 & 10 & $4: 1$ & 10 & 37.52 \\
\hline S/C14 & - & 50 & 10 & $5: 1$ & 10 & 38.82 \\
\hline S/C15 & - & 60 & 10 & $6: 1$ & 10 & 39.80 \\
\hline
\end{tabular}

G: Grass; S: Silage; C: Cow dung, G/C: Co-digestion of grass with cow dung, S/C: Co-digestion of silage with cow dung, $\mathrm{C} / \mathrm{N}$ ratio was calculated based on the co-digestion of grass and silage with cow dung.

Table 2. MP, methane content, methane production rate ( $\mathrm{Rm}$ ) and methane yield (MY) by self-fermentation of a co-digestion of Napier grass with cow dung and silage with cow dung.

\begin{tabular}{|c|c|c|c|c|c|c|}
\hline $\begin{array}{l}\text { Experiment } \\
\text { Code }\end{array}$ & $\begin{array}{c}\text { Final } \\
\mathrm{pH}\end{array}$ & $\begin{array}{c}\mathrm{MP} \\
\left(\mathrm{mL} \mathrm{CH}_{4} / \mathrm{L}\right)\end{array}$ & 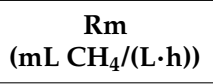 & $\begin{array}{l}\text { Lag Phase } \\
\text { (h) }\end{array}$ & $\begin{array}{c}\mathrm{CH}_{4} \text { Content } \\
\text { (\%) }\end{array}$ & $\begin{array}{c}\mathrm{MY} \\
\left(\mathrm{mL} \mathrm{CH}_{4} / \mathrm{g}-\mathrm{VS}_{\text {added }}\right)\end{array}$ \\
\hline G/C1 & 7.01 & 1765 & 2.26 & 153.58 & 66 & 176.66 \\
\hline $\mathrm{G} / \mathrm{C} 2$ & 7.17 & 2566 & 4.72 & 190.83 & 64 & 171.17 \\
\hline G/C3 & 7.33 & 3394 & 6.27 & 165.53 & 72 & 168.82 \\
\hline G/C4 & 7.36 & 3876 & 6.85 & 189.75 & 68 & 155.10 \\
\hline G/C5 & 7.33 & 4716 & 11.08 & 253.39 & 70 & 157.27 \\
\hline $\mathrm{G} / \mathrm{C} 6$ & 7.38 & 4209 & 12.69 & 457.34 & 70 & 120.30 \\
\hline $\mathrm{S} / \mathrm{C} 1$ & 7.55 & 1847 & 2.46 & 126.11 & 63 & 184.94 \\
\hline $\mathrm{S} / \mathrm{C} 2$ & 7.54 & 2741 & 5.59 & 156.07 & 63 & 182.89 \\
\hline S/C3 & 7.47 & 3365 & 1.78 & 373.38 & 63 & 168.34 \\
\hline $\mathrm{S} / \mathrm{C} 4$ & 7.28 & 4582 & 2.36 & 394.37 & 70 & 183.36 \\
\hline S/C5 & 7.23 & 4952 & 2.45 & 337.03 & 68 & 165.14 \\
\hline S/C6 & 7.16 & 5000 & 2.21 & 452.45 & 62 & 142.91 \\
\hline
\end{tabular}

G: Grass; S: Silage; C: Cow dung, G/C: Co-digestion of grass with cow dung, S/C: Co-digestion of silage with cow dung. 
An increase of the ratio of grass with cow dung and silage with cow dung greater than 1:1 resulted in an increase in MP. In contrast, MY decreased when the ratio of grass with cow dung and silage to cow dung increased greater than 1:1. This contradicts the previous sentence. An increase of the ratio of grass with cow dung and silage with cow dung ratio greater than 1:1 resulted in a higher $\mathrm{C} / \mathrm{N}$ ratio (33.09-46.99, Table 1) than the optimum range of 20-30 [26]. This results in adverse effects on methane production process [26]. The low MY obtained might be caused by the imbalance between hydrolytic, fermentative, and acetogenic bacteria, and methanogenic archaea [27]. The imbalances are caused by an unsuitable substrate ratio, low $\mathrm{pH}$, and accumulation of organic acids, high total ammonia-nitrogen and free ammonia content [28]. A mixing ratio of 1:1 had the shortest lag phase (Table 1) suggesting a short hydrolysis step. Hydrolysis is a rate limiting step during anaerobic digestion processes [10]. The length of the lag phase is important for the efficiency of AD [10]. However, there was no significantly difference in methane content at different mixing ratios (Table 3). The results indicated that the indigenous microorganisms present in the co-digestion of grass with cow dung, silage with cow dung and in cow dung are capable of degrading and converting the grass and silage to methane. A mixing ratio of 1:1 is found to be a suitable mixing ratio due to the highest MY obtained and the shortest lag phase (Table 3). Xie et al. [29] also reported that the highest MY from co-digestion of pig manure with silage occurred at a mixing ratio of 1:1.

Table 3. MP, methane content, Rm and MY from a co-digestion of Napier grass with cow dung and silage with cow dung by self-fermentation.

\begin{tabular}{|c|c|c|c|c|c|c|}
\hline $\begin{array}{l}\text { Experiment } \\
\text { Code }\end{array}$ & $\begin{array}{c}\text { Final } \\
\mathrm{pH}\end{array}$ & $\begin{array}{c}\mathrm{MP} \\
\left(\mathrm{mL} \mathrm{CH}_{4} / \mathrm{L}\right)\end{array}$ & $\begin{array}{c}\mathrm{Rm} \\
\left(\mathrm{mL} \mathrm{CH}_{4} /(\mathrm{L} \cdot \mathrm{h})\right)\end{array}$ & $\begin{array}{l}\text { Lag Phase } \\
\text { (h) }\end{array}$ & $\begin{array}{c}\mathrm{CH}_{4} \text { Content } \\
(\%)\end{array}$ & $\begin{array}{c}\mathrm{MY} \\
\left(\mathrm{mL} \mathrm{CH}_{4} / \mathrm{g}-\mathrm{VS}_{\text {added }}\right)\end{array}$ \\
\hline $\mathrm{G} / \mathrm{C} 7$ & 7.37 & 2921 & 2.69 & 137.71 & 62 & 194.73 \\
\hline $\mathrm{G} / \mathrm{C} 8$ & 7.37 & 3169 & 2.53 & 160.85 & 62 & 158.55 \\
\hline G/C9 & 7.37 & 3355 & 2.76 & 145.20 & 61 & 134.18 \\
\hline S/C7 & 7.33 & 2976 & 2.08 & 153.38 & 64 & 198.39 \\
\hline $\mathrm{S} / \mathrm{C} 8$ & 7.24 & 3226 & 1.42 & 133.13 & 63 & 161.35 \\
\hline S/C9 & 7.49 & 3251 & 2.68 & 151.03 & 62 & 130.12 \\
\hline
\end{tabular}

The morphological alteration of grass and silage at the initial and final methane production process was investigated using scanning electron microscope (SEM). Grass shows a smooth surface (Figure 1A) while a destroyed surface of the native silage was observed. This is possibly due to a degradation of cellulose and hemicellulose by bacteria during an ensiling [30,31]. After the end of methane fermentation process, the morphological of grass and silage were much destroyed and disorganized caused by microbial driven decomposition process (Figure 1C,D).

In order to enhance methane production, the cow dung concentration was increased to 20,30 and $40 \mathrm{~g}-\mathrm{VS} / \mathrm{L}$ (G/C7-G/C9 and S/C7-S/C9) while keeping a constant grass and silage concentration at $10 \mathrm{~g}-\mathrm{VS} / \mathrm{L}$. This resulted in a mixing ratio of 1:2,1:3, and 1:4, respectively (Table 4). MY from co-digestion of grass with cow dung of 194.73, 158.55, $134.18 \mathrm{~mL} \mathrm{CH}_{4} / \mathrm{g}$-VS $\mathrm{S}_{\text {added }}$ and MY from co-digestion of silage with cow dung of $198.39,161.35,130.12 \mathrm{~mL} \mathrm{CH}_{4} / \mathrm{g}$-VS ${ }_{\text {added, }}$, respectively, were obtained at respective mixing ratio of 1:2, 1:3 and 1:4 (Table 3). A maximum Rm of 2.76 and $2.68 \mathrm{~mL}$ $\mathrm{CH}_{4} /(\mathrm{L} \cdot \mathrm{h})$ from co-digestion of grass with cow dung and silage with cow dung, respectively, were obtained at a mixing ratio of 1:4 (Table 3). 

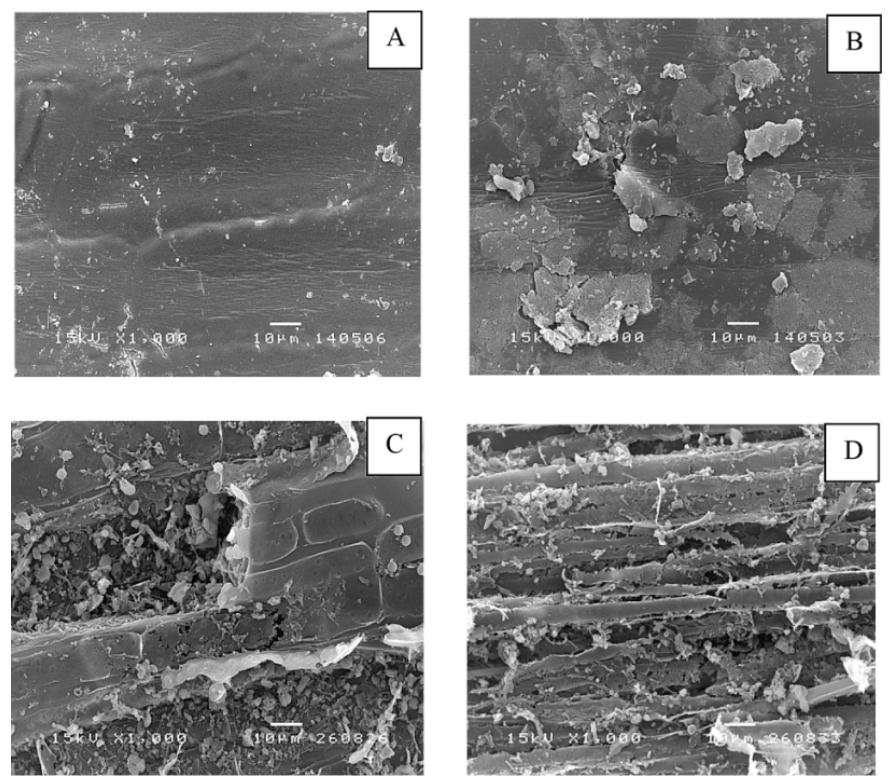

Figure 1. Scanning electron microscope of Napier grass (A) and silage (B), grass and silage after methane production (co-digestion of grass with cow dung at the ratio of 1:1 (C) and co-digestion of silage with cow dung at the ratio of 1:1 (D)).

Table 4. Experimental set up for methane production from a co-digestion of Napier grass with cow dung and silage with cow dung by self-fermentation at various cow dung concentrations, and a fixed substrate concentration of $10 \mathrm{~g}-\mathrm{VS} / \mathrm{L}$.

\begin{tabular}{cccccc}
\hline $\begin{array}{c}\text { Experimental } \\
\text { Code }\end{array}$ & $\begin{array}{c}\text { Grass } \\
\text { (g-VS/L) }\end{array}$ & $\begin{array}{c}\text { Silage } \\
\text { (g-VS/L) }\end{array}$ & $\begin{array}{c}\text { Cow Dung } \\
\text { (g-VS/L) }\end{array}$ & $\begin{array}{c}\text { Grass/Silage to Cow } \\
\text { Dung Ratio (g-VS/g-VS) }\end{array}$ & C/N Ratio \\
\hline G/C7 & 10 & - & 20 & $1: 2$ & 26.91 \\
G/C8 & 10 & - & 30 & $1: 3$ & 25.10 \\
G/C9 & 10 & - & 40 & $1: 4$ & 24.12 \\
S/C7 & - & 10 & 20 & $1: 2$ & 24.54 \\
S/C8 & - & 10 & 30 & $1: 3$ & 23.41 \\
S/C9 & - & 10 & 40 & $1: 4$ & \\
\hline
\end{tabular}

G: Grass; S: Silage; C: Cow dung, G/C: Co-digestion of grass with cow dung, S/C: Co-digestion of silage with cow dung, $\mathrm{C} / \mathrm{N}$ ratio was calculated based on the co-digestion of grass and silage with cow dung.

MY decreased with an increase in the amount of cow dung. A high amount of cow dung resulted in a high nitrogen content in the fermentation system. Therefore, a low MY might be caused by the low carbon source for methanogen and the accumulation of free ammonia concentration from the cow dung. Xie et al. [29] reported that free $\mathrm{NH}_{3}$ concentration of $210 \mathrm{mg} / \mathrm{L}$ was obtained from co-digestion of pig manure with silage at a mixing ratio of 3:1 while Wu et al. [32] found that inhibition of methanogens by free $\mathrm{NH}_{3}$ was reversible when the free $\mathrm{NH}_{3}$ concentration was as high as $998 \mathrm{mg} / \mathrm{L}$. The varying inhibition concentrations of free $\mathrm{NH}_{3}$ is attributed to the differences in substrates and inocula, environmental conditions and acclimation periods [29].

\subsection{Methane Production from Co-Digestion of Grass with Cow Dung and Silage with Cow Dung by Bioaugmentation of Anaerobic Sludge}

The MP, Rm, MY and methane content were obtained from a grass with cow dung and silage with cow dung at different mixing ratios augmented with anaerobic sludge as showed in Table 5. A methane content in all experiments ranged from $59-65 \%$ and $60-65 \%$ from a co-digestion of grass with cow dung and silage with cow dung, respectively. Methane contents from the co-digestion of silage with pig manure were also found in the ranges of 59-65\% [29]. 
Table 5. Methane production (MP), methane content, methane production rate ( $\mathrm{Rm}$ ) and methane yield (MY) from a co-digestion of Napier grass with cow dung and silage with cow dung by bioaugmentation with anaerobic sludge.

\begin{tabular}{|c|c|c|c|c|c|c|}
\hline $\begin{array}{l}\text { Experiment } \\
\text { Code }\end{array}$ & $\begin{array}{c}\text { Final } \\
\mathrm{pH}\end{array}$ & $\begin{array}{c}\mathrm{MP} \\
\left(\mathrm{mL} \mathrm{CH}_{4} / \mathrm{L}\right)\end{array}$ & 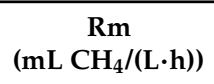 & $\begin{array}{l}\text { Lag Phase } \\
\text { (h) }\end{array}$ & $\begin{array}{c}\mathrm{CH}_{4} \text { Content } \\
(\%)\end{array}$ & $\begin{array}{c}\mathrm{MY} \\
\left(\mathrm{mL} \mathrm{CH}_{4} / \mathrm{g}-\mathrm{VS}_{\text {added }}\right)\end{array}$ \\
\hline $\mathrm{G} / \mathrm{C} 10$ & 7.01 & 1168 & 1.72 & 70.86 & 59 & 116.65 \\
\hline $\mathrm{G} / \mathrm{C} 11$ & 7.17 & 2107 & 4.22 & 34.65 & 61 & 140.48 \\
\hline $\mathrm{G} / \mathrm{C} 12$ & 7.93 & 3592 & 6.18 & 285.48 & 65 & 179.59 \\
\hline $\mathrm{G} / \mathrm{C} 13$ & 7.36 & 4258 & 4.58 & 256.21 & 61 & 170.31 \\
\hline $\mathrm{G} / \mathrm{C} 14$ & 7.33 & 3503 & 3.03 & 198.34 & 61 & 116.76 \\
\hline G/C15 & 7.38 & 2956 & 3.80 & 264.77 & 61 & 84.46 \\
\hline S/C10 & 7.61 & 1419 & 2.11 & 41.42 & 60 & 141.88 \\
\hline $\mathrm{S} / \mathrm{C} 11$ & 7.65 & 2687 & 4.47 & 19.34 & 63 & 179.15 \\
\hline $\mathrm{S} / \mathrm{C} 12$ & 7.47 & 4162 & 5.91 & 142.74 & 65 & 208.11 \\
\hline $\mathrm{S} / \mathrm{C} 13$ & 7.28 & 5051 & 6.45 & 205.26 & 63 & 202.06 \\
\hline S/C14 & 7.23 & 5454 & 6.01 & 228.56 & 65 & 181.81 \\
\hline $\mathrm{S} / \mathrm{C} 15$ & 7.16 & 4886 & 4.61 & 369.85 & 63 & 139.59 \\
\hline
\end{tabular}

MY increased with an increase in the ratio of grass with cow dung and silage with cow dung from 1:1 to 3:1 (g-VS/g-VS). MY was decreased when the ratio of grass with cow dung and silage with cow dung were greater than 3:1 (g-VS/g-VS) (Table 5). The grass with cow dung and silage with cow dung ratio of 3:1 gave the maximum MY of 179.59 and $208.11 \mathrm{~mL} \mathrm{CH}_{4} / \mathrm{g}-\mathrm{VS}_{\text {added, }}$, respectively (Table 5). A high MY observed at the ratio 3:1 implied that at a suitable $\mathrm{C} / \mathrm{N}$ ratio, the microbial growth and substrate utilization were enhanced [33]. Thus, a methane production was improved. For a co-digestion of grass with cow dung and silage with cow dung, manure provide buffering capacity and a wide range of nutrients [34], while the addition of grass and silage containing high carbon content (43-45\%) balances the $\mathrm{C} / \mathrm{N}$ ratio. Co-digestion of silage with cow dung gave a MY higher than a co-digestion of grass with cow dung might be due to the fact that the silage is easier to be degraded than grass. During the ensiling, the grass is degraded by microorganisms resulting in more biodegradability structure of silage than grass [35].

The final $\mathrm{pH}$ in all experiments ranged from 7.01-7.93 for a co-digestion of grass with cow dung and silage with cow dung (Table 5). $\mathrm{pH}$ range of 7.00-8.00 was suitable for obtaining a high biogas production and degradation of VS [36]. Methanogenic bacteria perform well within a $\mathrm{pH}$ range of 6.80-7.20 while drop in $\mathrm{pH}$ below 6.60 might inhibit methanogens [1]. The present study shows that the $\mathrm{pH}$ in the range of 7.01-7.55 is suitable for methanogens.

Under the optimum conditions, the MY of $179.59 \mathrm{~mL} \mathrm{CH}_{4} / \mathrm{g}-\mathrm{VS}_{\text {added }}$ obtained by bioaugmentation of anaerobic sludge to a co-digestion of grass with cow dung was comparable to the self-fermentation of grass with cow dung (176.66 $\mathrm{mL} \mathrm{CH}_{4} / \mathrm{g}$-VS added $)$. However, a maximum MY $\left(208.11 \mathrm{~mL} \mathrm{CH}_{4} / \mathrm{g}\right.$-VS $\left.\mathrm{Sdded}_{\text {ad }}\right)$ obtained by bioaugmentation of anaerobic sludge to a co-digestion of silage with cow dung was significantly higher $(p<0.05)$ than MY of $184.94 \mathrm{~mL} \mathrm{CH}_{4} / \mathrm{g}-\mathrm{VS}_{\text {added }}$ obtained from self-fermentation of silage with cow dung. Based on our findings, the bioaugmentation technique effectively enhanced the MY from co-digestion of silage with cow dung only, but could not enhance the MY obtained from co-digestion of grass with cow dung. The discrepancy might be due to the different in the structure of grass and silage. During the ensiling, the compression of the material in tightly closed containers established the anaerobic condition. This promotes the growth of lactic acid bacteria. In consequence, the lactic acid produced by lactic acid bacteria can loosen the structure and allow more biodegradability of the silage by the bioaugmended microbial consortium. In contrast, the structure of grass was more complex comprising of lignin, hemicellulose and crystalline cellulose. Therefore, the accession of the microorganisms augmended into the fermentation system of grass is more difficult than the silage. 


\subsection{Microbial Community and Methane Fermentation Performance}

The bacteria and archaea community detected in a co-digestion of grass with cow dung and silage with cow dung by self-fermentation were analyzed by polymerase chain reaction-denaturing gradient gel electrophoresis (PCR-DGGE) (Figure 2). Main bacteria found under the optimum conditions i.e., a co-digestion of grass with cow dung (lane A) and silage with cow dung (lane B) ratio of 1:1 by self-fermentation were Aciditerrimonas sp. (band 1), Acetoanaerobium sp. (bands 2 and 4), Ruminococcus sp. (band 3), Clostridium sp. (band 5) and Parapedobacter sp. (band 6). Ruminococcus sp. and Parapedobacter sp. play substantial roles in degrading polysaccharides of plant biomass and utilize the complex organic substrates in aquatic environments such as cellulose and other biomacromolecules [37]. Aciditerrimonas sp., Acetoanaerobium sp., and Clostridium sp. can convert the simple sugar to VFAs resulted in hydrogen and carbon dioxide as a by-products. The archaea community found in a methane production by self-fermentation from the co-digestion of grass with cow dung (lane C) and silage with cow dung (lane D) were Methanomicrobium sp. (bands 2 and 4), Methanoculleus sp. (band 6) and Metahnoregula sp. (band 3). These microorganisms are able to utilize VFAs, hydrogen and carbon dioxide as the substrate for a methane production occurred in step 4.

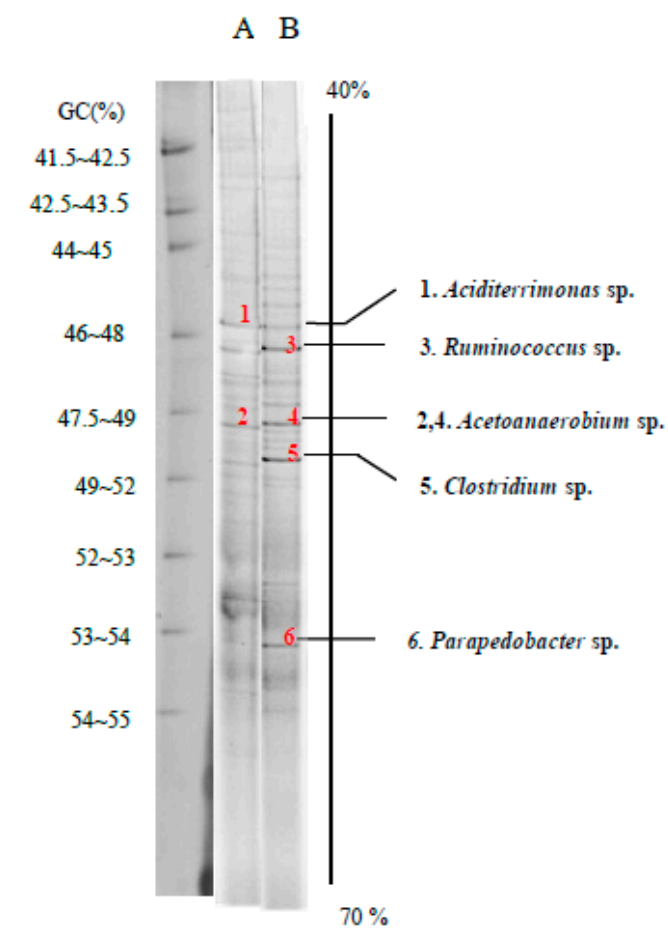

(Bacteria)

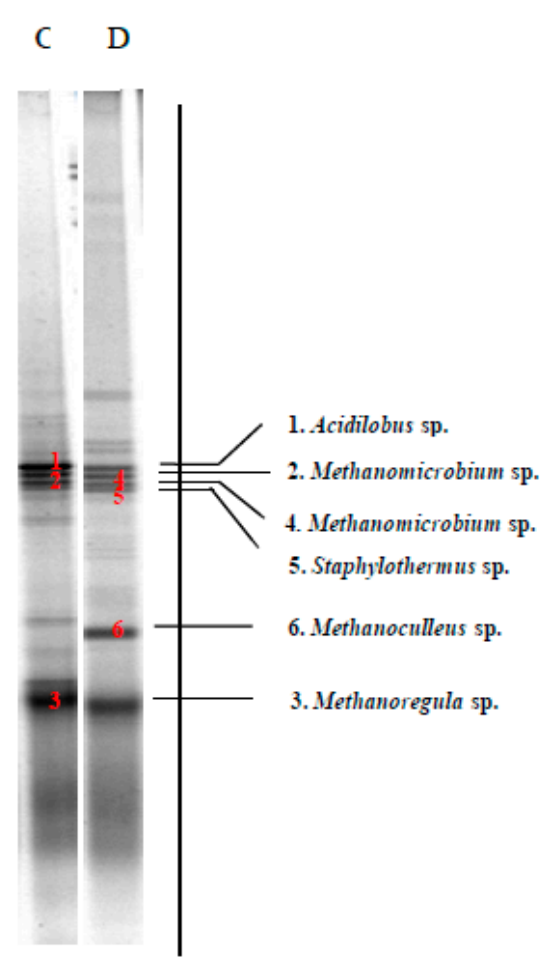

(Archaea)

Figure 2. Polymerase chairn reaction and denautring gradeint gel electrophoresis (PCR-DGGE) profiles of bacteria and archaea at the end of a methane production from co-digestion of grass with cow dung and silage with cow dung by self-fermentation at the optimal mixing ratio of 1:1. Lanes A and B: bacteria community from co-digestion of grass with cow dung and silage with cow dung, respectively. Lanes C and D: archaea community from co-digestion of grass with cow dung and silage with cow dung, respectively.

The bacteria and archaea community found in a methane production by bioaugmentation of anaerobic sludge to a co-digestion of grass with cow dung and silage with cow dung was depicted in Figure 3. The cellulolytic bacteria found in bioaugmentation of anaerobic sludge to a co-digestion of grass with cow dung (lane A) and silage with cow dung (lane B) were Clostridium sp. (band 9) and Unclassified Ruminococcaceae (bands 2 and 12). The hydrolytic bacteria found in the bioaugmentation 
treatments were Clostridium sp. (band 9), Enterococcus sp. (band 10), Thalassolituus sp. (bands 1 and 11), Unclassified Ruminococcaceae (bands 2 and 12), Anaerobacter sp. (bands 3 and 13) and Geobacter sp. (band 4), respectively. Pseudoalteromonas sp. (band 5) and Peptoniphilus sp. (band 8) were hydrolytic bacteria found in the bioaugmentation treatments of a co-digestion of grass with cow dung, while Candidatus sp. (band 14) was found in the bioaugmentation treatments of a co-digestion of silage with cow dung. Acidogenic bacteria found in bioaugmentation treatments of a co-digestion of grass with cow dung and silage with cow dung were Enterobacter sp. (band 10), Clostridium sp. (band 9) and Unclassified Ruminococcaceae (bands 2 and 12). The acetogenic bacteria found in the bioaugmentation treatment of a co-digestion of grass with cow dung was Acetoanaerobium sp. (band 6) and Clostridium sp. (band 9). Clostridium sp. and Enterococcus sp. are well-known hydrogen producing bacteria capable of converting and hydrolyzing polysaccharides to short chain VFAs, hydrogen and carbon dioxide as the primary fermentation products in the AD process [38]. A long chain VFAs such as butyrate, propionate can be converted to acetate by Acetoanaerobium sp. VFAs, hydrogen and carbon dioxide can be further converted to methane by methanogenic bacteria using two paths as follows [39]:

$$
\begin{gathered}
\mathrm{CO}_{2}+4 \mathrm{H}_{2} \rightarrow \mathrm{CH}_{4}+2 \mathrm{H}_{2} \mathrm{O} \quad \text { Hydrogenotrophic methanogens } \\
\mathrm{CH}_{3} \mathrm{COOH} \rightarrow \mathrm{CH}_{4}+\mathrm{CO}_{2} \quad \text { Acetoclastic methanogens }
\end{gathered}
$$
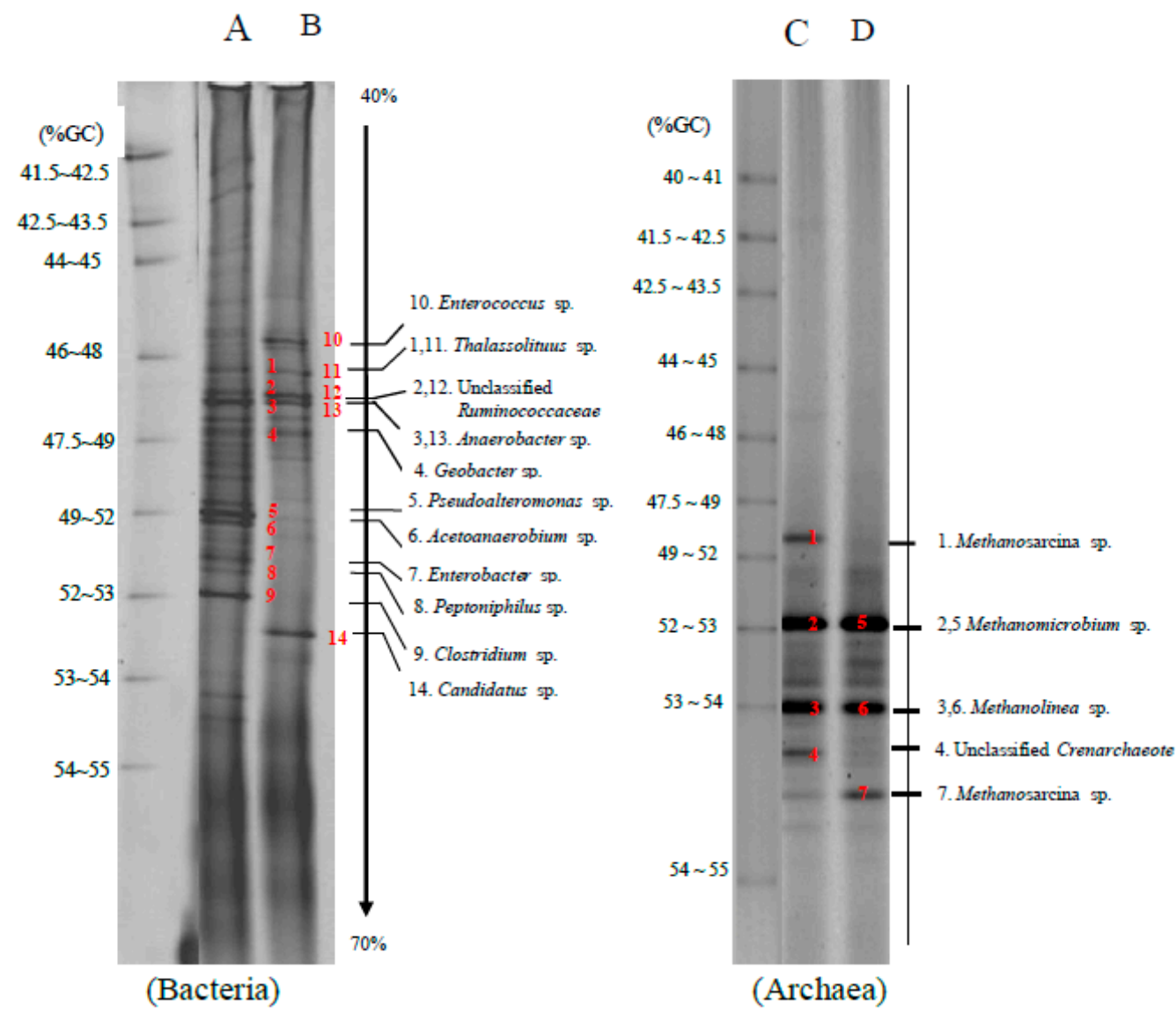

Figure 3. Polymerase chairn reaction and denautring gradeint gel electrophoresis (PCR-DGGE) profiles of bacteria and archaea at the end of the methane production from a co-digestion of grass with cow dung and silage with cow dung by anaerobic sludge at the optimal mixing ratio of 3:1. Lanes A and B: bacteria community from a co-digestion of grass with cow dung and silage with cow dung, respectively. Lanes $C$ and D: archaea community from a co-digestion of grass with cow dung and silage with cow dung, respectively. 
The archaea community is found in bioaugmentation of anaerobic sludge to a co-digestion of grass with cow dung (lane C) and silage with cow dung (lane D) comprised of Methanosarcina sp. (bands 1 and 7), Methanolinea sp. (bands 3 and 6), Methanomicrobium sp. (bands 2 and 5) and Unclassified Crenarchaeote. (band 4). Both Methanomicrobium sp. and Methanolinea sp. were hydrogenotrophic methanogens that can utilize hydrogen and carbon dioxide as the substrate to produce methane (Equation (1)) [40]. Methanosarcina sp. is a well-known as methanogenic bacterium capable of converting acetic acid to methane (Equation (2)). Since the main methanogens were Methanomicrobium sp. and Methanolinea sp. suggesting that the main methane production process from a co-digestion of grass with cow dung and silage with cow dung is a hydrogenotrophic methanogenic pathway (Equation (1)). The presence of Methanosarcina sp. suggested that the other methane production process was acetoclastic methanogenic pathway (Equation (2)).

The bacteria community found in self-fermentation and bioaugmentation processes was quite different in terms of species and quantity but the roles were similar. All of bacteria found under the optimum conditions of a self-fermentation (1:1) and bioaugmentation (3:1) process can convert substrate (grass, silage, and cow dung) to VFAs, hydrogen and carbon dioxide. Therefore, the important indications for methane production performance were substrate concentration (VFAs, hydrogen and carbon dioxide), the amount and types of archaea founded in the fermentation system.

Under the optimum conditions of a co-digestion of grass with cow dung and silage with cow dung at a mixing ratio of 1:1 by self-fermentation, the methanogens were Methanomicrobium sp. and Methanoculleus sp. At the optimum conditions of a co-digestion of grass with cow dung and silage with cow dung at a mixing ratio of 3:1 by bioaugmentation treatments, the methanogens were Methanosarcina sp., Methanomicrobium sp., and Methanolinea sp. The comparison of archaea population in both fermentation processes showed that the band of methanogens found in the bioaugmentation treatments were more predominant than self-fermentation treatments of a co-digestion of grass with cow dung and silage with cow dung. These results are correlated with a high MY obtained by bioaugmentation of anaerobic sludge into a co-digestion of silage with cow dung. However, predominant of archaea population in a co-digestion of grass with cow dung in a bioaugmentation treatment did not significantly enhance the MY (Tables 1 and 5). The MY obtained from bioaugmentation treatment was higher than a self-fermentation of silage with cow dung. The discrepancy might be due to the bioaugmentation treatment was predominant with methanogens than a self-fermentation. The bands of the methanogens found in bioaugmentation treatment had a higher intensity than self-fermentation. A predominant of a methanogens found in bioaugmention treatment of a co-digestion of silage with cow dung was correlated with the maximum MY obtained. The results implied that the predominant methanogens efficiently converted the VFAs, hydrogen and carbon dioxide to methane. In addition, the differences of $M Y$ at various $\mathrm{C} / \mathrm{N}$ ratio might be caused by the coordinate matching of antagonistic and symbiotic relationships among different species. Our results demonstrated that the improved MY depended on the $\mathrm{C} / \mathrm{N}$ ratio of grass with cow dung and silage with cow dung and also the biogumentation of anaerobic sludge. In addition, the changes in the ratio of grass with cow dung and silage with cow dung caused the changes in indigenous bacteria and archaea community structure. Therefore, we speculated that a normal flora resided in silage and cow dung may serve as the source of inoculum to produce methane.

\subsection{Methane Production from Solid Residue Left over after Methane Production Process}

This experiment was conducted in order to recover total energy from grass and silage by producing methane from the solid residues left over after the methane production process at the optimum ratio of grass with cow dung and silage with cow dung of 3:1 by a bioaugmentation treatment. The solid residue was subjected to different pretreatment methods including grinding, alkaline, enzyme, grinding plus enzyme, and alkaline plus enzyme. The effects of different pretreatment methods on cumulative MP are shown in Figure 4. The pretreated solid residues showed a significant effect on cumulative MP (Figure 4). The results indicate that the enzyme pretreatment method was suitable to degrade 
cellulose and hemicellulose in grass, silage and some macromolecules in cow dung resulted in a higher cumulative MP (Figure 4) and MY (Table 6).

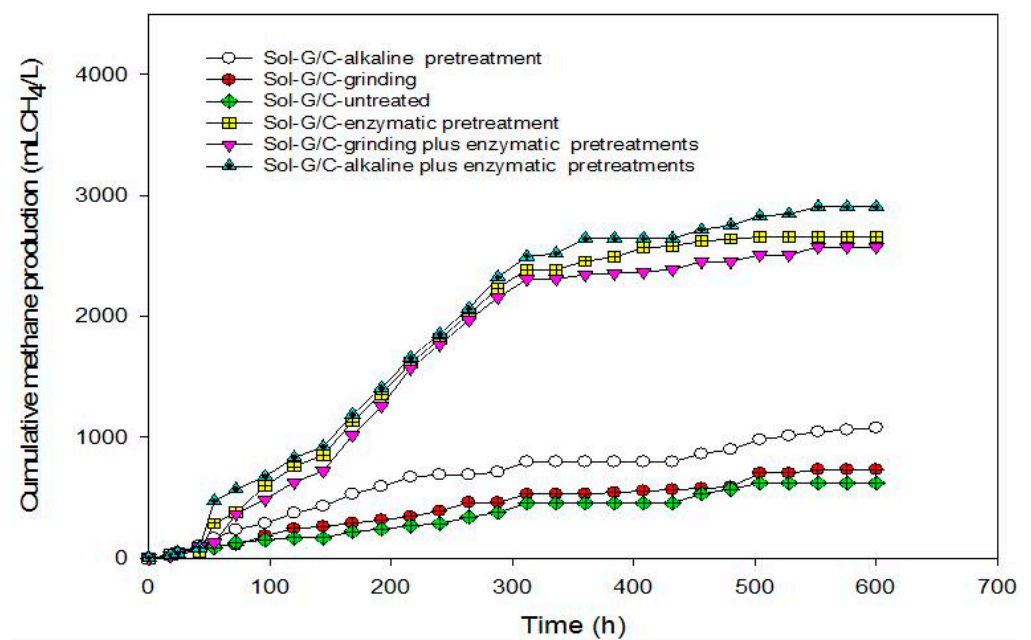

(A)

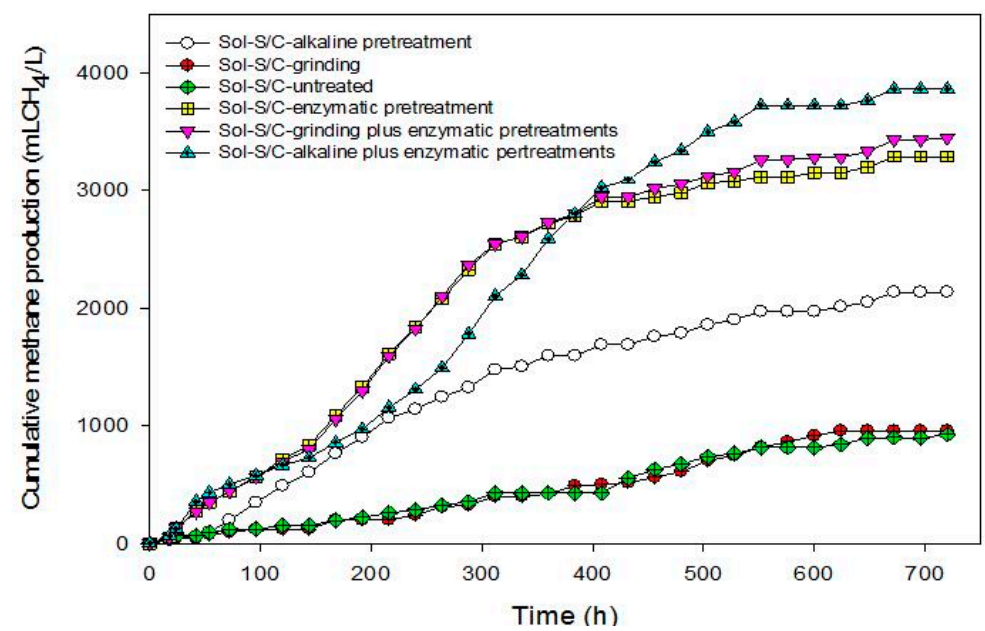

(B)

Figure 4. Cumulative methane production profiles of solid residues from a co-digestion of grass with cow dung (Sol-G/C) (A) and silage with cow dung (Sol-S/C) (B) subjected to different pretreatment methods.

Table 6. MP, Rm, MY of pre-treated solid residues from one-stage methane production.

\begin{tabular}{|c|c|c|c|c|}
\hline Treatment & $\begin{array}{c}\mathrm{MP} \\
\left(\mathrm{mL} \mathrm{CH}_{4} / \mathrm{L}\right)\end{array}$ & 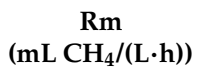 & $\begin{array}{c}\mathrm{CH}_{4} \text { Content } \\
(\%)\end{array}$ & $\begin{array}{c}\text { MY } \\
\left(\mathrm{mL} \mathrm{CH}_{4} / \mathrm{g}-\mathrm{VS}_{\text {added }}\right)\end{array}$ \\
\hline Sol-G/C-Untreated & 154 & 1.32 & 39 & 6.84 \\
\hline Sol-G/C-Alkaline pretreatment & 589 & 2.86 & 50 & 71.81 \\
\hline Sol-G/C-Enzyme pretreatment & 957 & 10.33 & 66 & 126.74 \\
\hline Sol-G/C-Grinding plus enzyme pretreatment & 896 & 10.48 & 67 & 117.53 \\
\hline Sol-S/C-Grinding & 577 & 1.76 & 48 & 20.88 \\
\hline Sol-S/C-Alkaline pretreatment & 1570 & 5.57 & 54 & 114.72 \\
\hline Sol-S/C-Enzyme pretreatment & 1380 & 10.02 & 67 & 96.76 \\
\hline Sol-S/C-Grinding plus enzyme pretreatment & 1453 & 9.88 & 70 & 103.67 \\
\hline Sol-S/C-Alkaline plus enzyme pretreatment & 3547 & 8.91 & 69 & 301.38 \\
\hline
\end{tabular}

Sol: Solid residue, Sol-G/C: Solid residues from a co-digestion of grass with cow dung at ratio of 3:1, Sol-S/C: Solid residues from a co-digestion of silage with cow dung at ratio of 3:1. 
Fourier transform infrared spectrometer (FTIR) spectra showed the structure differences among untreated, alkaline pretreatment and enzyme pretreatment (Figure 5). Application of pretreatment caused the changes in peak intensity at the wave number ranges from $1063-1700 / \mathrm{cm}$ in comparison to untreated materials (control). The changes in peak intensity at these ranges is correlated with the changes in lignin structure $(1400-1700 / \mathrm{cm})$ [41] and crystallinity of cellulose $(1100-1200 / \mathrm{cm})$ [42]. The results implied that the alkaline and enzyme pretreatment can partially destroy the lignin and crystallinity of cellulose inside grass and silage. Solid residues from co-digestion of grass with cow dung and silage with cow dung pretreated with enzyme and alkaline showed a different spectrum in comparison to untreated solid residues from a co-digestion of grass with cow dung and silage with cow dung (Figure 5).

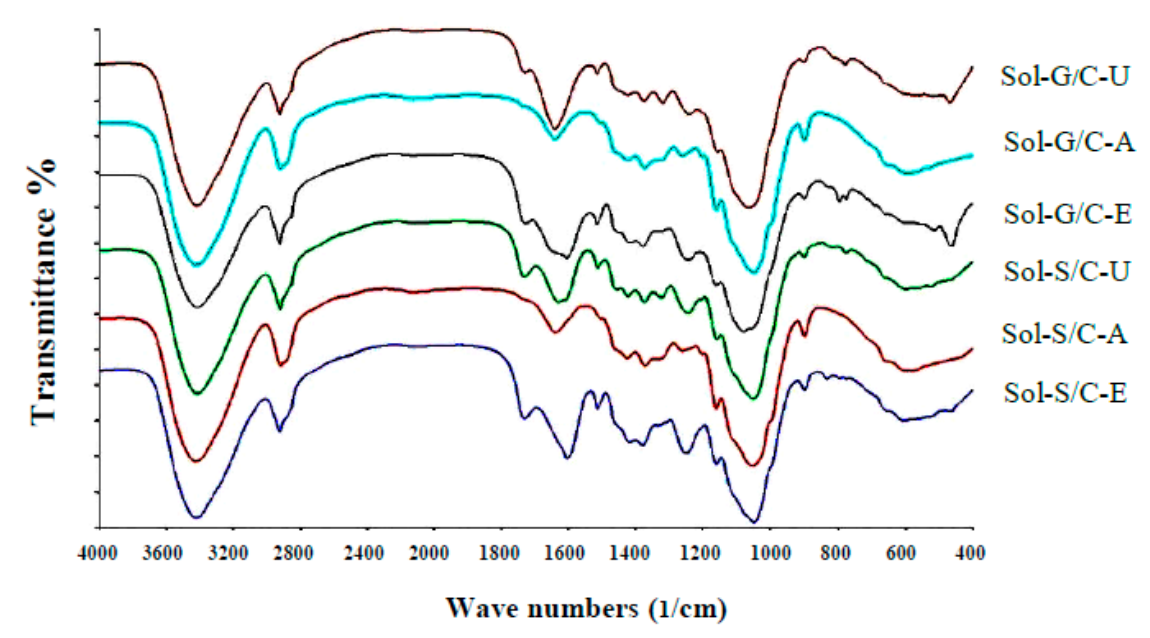

Figure 5. FTIR of spectra of solid residues from a co-digestion of grass with cow dung (Sol-G/C) and silage with cow dung (Sol-S/C) subjected to different pretreatment methods. (Untreated solid residues of grass with cow dung (Sol-G/C-U); solid residues of grass with cow dung pretreated by alkaline pretreatment (Sol-G/C-A); enzyme pretreatment (Sol-G/C-E); Untreated solid residues of silage with cow dung (Sol-S/C-U); solid residues of silage with cow dung pretreated by an alkaline pretreatment (Sol-S/C-A); enzyme pretreatment (Sol-S/C-E)).

The intensity of the peak, approximately $1600 / \mathrm{cm}$, was lower after pretreatment than untreated solid residues of a co-digestion of grass with cow dung and silage with cow dung, indicating that the structure of lignin was changed after the pretreatments. The previous observations on spectra showed that the aromatic skeletal/C-O stretching ratio, $\mathrm{R}=\mathrm{I}(1157 / \mathrm{cm}) / \mathrm{I}(1063 / \mathrm{cm})$, represent the crystallinity of cellulose. As the aromatic skeletal/C-O stretching ratio increase, the crystallinity decrease [42]. The aromatic skeletal/C-O stretching ratio of solid residue of a co-digestion of grass with cow dung pretreated with an alkaline and enzyme were found to increase from 0.70 to 0.17 and 0.07 to 0.13 , respectively, and for the solid residue of co-digestion of silage with cow dung were found to increase from 0.12 to 0.20 and 0.12 to 0.14 , respectively. A high aromatic skeletal/C-O stretching ratio indicated that the pretreatment effectively destroys the lignin structure and disrupt the crystalline cellulose to reduce crystallinity. The highest aromatic skeletal/C-O stretching ratio was found with the alkali pretreatment method indicating that the alkali method has the highest efficiency to degrade lignin compound and disrupt the crystalline cellulose. Alkali pretreatment leads to an increase in porosity and internal surface area, structural swelling, a decrease in the degree of polymerization and crystallinity and a breakdown of links between lignin and other polymers [43]. These would allow a better accessibility of cellulose and hemicellulose by enzymes and [17,24]. More accessible cellulose is the key success of the methane production process due to it can be easily degraded and converted to methane by microorganisms [44]. In this study, solid residues from co-digestion of grass with cow dung and silage with cow dung pretreated with alkali gave 10.49 and 13.42-fold increases in MY in 
comparison to the untreated solid residues of co-digestion of grass with cow dung and silage with cow dung. However, the MP obtained from solid residue of grass with cow dung pretreated by alkali was 1.76 times less than MP obtained from solid residue of grass with cow dung pretreated by enzyme pretreatment. Thus, the alkaline pretreatment can remove lignin and yield accessible cellulose as a substrate for methanogens, while the enzyme pretreatment can specifically degrade the cellulose to sugars resulting in a higher obtained MP.

Based on these results, in order to enhance the methane production from solid residue obtained from a co-digestion of grass with cow dung and silage with cow dung the combination of chemical and physical with enzyme pretreatments method were conducted. Grinding plus enzyme and alkali plus enzyme pretreatment methods were used. The results showed that the combined pretreatment enhanced the MY from solid residue obtained from a co-digestion of grass with cow dung and silage with cow dung (Table 6). Alkali plus enzyme pretreatment gave the maximum cumulative MP from the solid residues from a co-digestion of grass with cow dung and silage with cow dung. The MP from the solid residue of silage with cow dung was higher than the solid residue of grass with cow dung in all treatments (Table 6). MP from pretreated solid residues was in the order of alkali plus enzyme pretreatment $>$ enzyme pretreatment $>$ grinding plus enzyme pretreatment $>$ alkaline pretreatment $>$ grinding $>$ untreated for solid residues from a co-digestion of grass with cow dung while alkali plus enzyme pretreatment $>$ alkali pretreatment $>$ grinding plus enzyme pretreatment $>$ enzyme pretreatment $>$ grinding $>$ untreated from silage with cow dung. MP from the combined pretreatment was higher than a sole pretreatment. A sole pretreatment does not provide efficient results due to its limited specific effect, e.g., $\mathrm{NaOH}$ mainly targets lignin, but not hemicellulose [45]. Maximum MP of 3,547 $\mathrm{mL} \mathrm{CH}_{4} / \mathrm{L}$ was obtained from the solid residues of a co-digestion of silage with cow dung pretreated by an alkali plus enzyme treatment. Moreover, alkali pretreatment can break the lignin barrier and disrupt the crystallinity of cellulose, thus increased the susceptibility of cellulose to enzyme $[41,46,47]$.

Results indicated that Rm was greatly improved after the pretreatment of solid residues obtained from a co-digestion of grass with cow dung and silage with cow dung. The untreated solid residues of grass with cow dung and silage with cow dung yielded a low $\mathrm{Rm}$ of 1.32 and $1.58 \mathrm{~mL} \mathrm{CH}_{4} /(\mathrm{L} \cdot \mathrm{h})$, respectively. The highest $\mathrm{Rm}$ of 10.33 and $10.02 \mathrm{~mL} \mathrm{CH}_{4} /(\mathrm{L} \cdot \mathrm{h})$ were obtained from the solid residues of grass with cow dung and silage with cow dung, respectively, pretreated by an enzyme pretreatment which are six times higher than that of the untreated sample $\left(1.32\right.$ and $1.58 \mathrm{~mL} \mathrm{CH}_{4} /(\mathrm{L} \cdot \mathrm{h})$, respectively). In contrast, the effects of grinding and alkali pretreatment on $\mathrm{Rm}$ were less obvious. Our results indicated that the enzymatic hydrolysis is much more efficient than the grinding and alkali pretreatment. Similarly, a maximum MY of 333.63 and $301.38 \mathrm{~mL} \mathrm{CH}_{4} / \mathrm{g}$-VS added, from the solid residues of grass with cow dung and silage with cow dung, respectively, were obtained by an alkali plus enzyme pretreatment. Alkali pretreatment is necessary for effective biogas generation from lignocellulosic biomass due to its high efficiency in delignification which can increase the accessibility of cellulose for the enzymatic reaction [48]. $\mathrm{NaOH}$ induces the saponification of the uronic bonds between hemicelluloses and lignin, swells the biomass and increases pore size, and also facilitates the diffusion of the hydrolytic enzymes [49]. Michalska and Ledakowicz [50] also reported that a combination of alkali treatment with enzymatic hydrolysis of Sorghum moench resulted in 30\% and 50\% higher MY than alkali and enzymatic treatment alone, respectively. The results from the combined alkali plus enzyme pretreatment improve MY about 50\% greater than the enzymatic hydrolysis alone which was coincided with the result of [48].

\subsection{Energy Production from a Co-Digestion of Grass with Cow Dung and Silage with Cow Dung by Self-Fermentation, Bioaugmentation and Pretreated Solid Residues}

The energy production from a co-digestion of grass with cow dung and silage with cow dung by self-fermentation, bioaugmentation and from pretreated solid residue were depicted in Figure 6 . The energy production of a co-digestion of grass with cow dung and silage with cow dung by 
self-fermentation were 7.08 and $7.41 \mathrm{~kJ} / \mathrm{g}$-VS $\mathrm{V}_{\text {added }}$ while the energy production from a co-digestion of grass with cow dung and silage with cow dung by bioaugmentation treatment were 7.20 and $8.34 \mathrm{~kJ} / \mathrm{g}-\mathrm{VS}_{\text {added, }}$, respectively (Figure 6). The energy production from a co-digestion of silage with cow dung by a bioaugmentation treatment was 1.18 times greater than self-fermentation. Therefore, the bioaugmentation of anaerobic sludge into a co-digestion of silage with cow dung showed a positive effect on biogas production and energy production.

The maximum energy production of solid residue from a co-digestion of grass with cow dung and silage with cow dung pretreated by an alkaline plus enzyme were 290.95 and $47.64 \mathrm{~kJ} / \mathrm{g}$-VS $\mathrm{V}_{\text {added, }}$, respectively (Figure 6). The energy production of solid residue from co-digestion of grass with cow dung and silage with cow dung pretreated by alkaline plus enzyme were 29.16 and 5.71 times, respectively, higher than a co-digestion of grass and silage with cow dung bioaugmended with the anaerobic sludge, respectively. These results revealed that the pretreatment of solid residue obtained from a co-digestion of grass with cow dung gave a better benefit in terms of increasing the energy production (Figure 7). The pretreatment method can destroy the crystalline cellulose inside grass and silage and gained more glucose which caused an increase in MP and MY. Therefore, an application of pretreatment methods on the solid residue left over after co-digestion of grass with cow dung was a good approach for totally recover the methane from lignocellulosic materials.

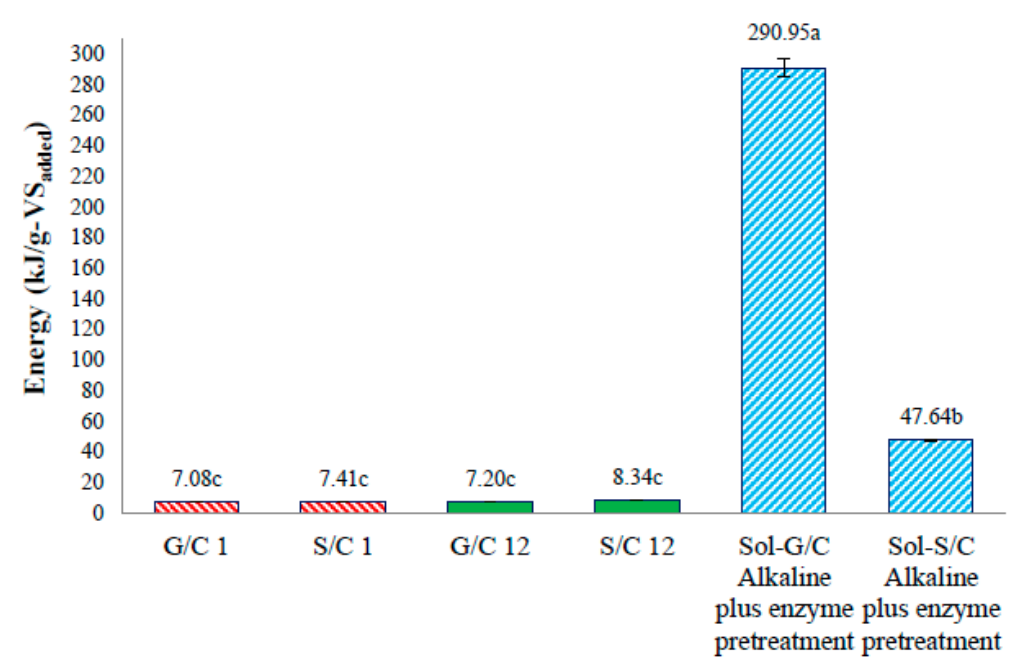

Figure 6. Energy production under the optimum conditions of a co-digestion of grass (G) with cow dung (C) and silage (S) with cow dung by self-fermentation (G/C1 and S/C1, respectively), bioaugmentaion (G/C12 and S/C12, respectively), and solid residues from a co-digestion of grass with cow dung (Sol-G/C) and silage with cow dung (Sol-S/C).

The overall energy production from co-digestion of grass with cow dung and silage with cow dung was depicted in Figure 7. The overall energy production from a co-digestion of grass with cow dung and silage with cow dung were 298.15 and $55.98 \mathrm{~kJ} / \mathrm{g}-\mathrm{VS}_{\text {added }}$ respectively. This implies that the use of $1 \mathrm{~g}$-VS of grass and cow dung at a ratio of 3:1 ( $0.75 \mathrm{~g}$-VS $\mathrm{Vrass}_{\text {gnd }}$ a.25 g-VS $\left.\mathrm{V}_{\text {cow dung }}\right)$ as the substrate to produce biogas via the bioaugmentation technique gave a maximum energy production of $298.15 \mathrm{~kJ}$, whereas the use of $1 \mathrm{~g}$-VS of silage and cow dung gave a maximum energy production of $55.98 \mathrm{~kJ}$. The power generation (watt) was then calculated by dividing overall energy production (J) by overall fermentation time (s). In this study, an overall fermentation time for biogas production from a co-digestion of grass with cow dung and silage with cow dung were approximately 87 days. Therefore, the power generation from co-digestion of grass with cow dung and silage with cow dung were 0.0397 and 0.007 watts, respectively. The amount of grass and cow dung were further estimated for establishing $1 \mathrm{MW}$ biomass power plant. In case of grass, $18.89 \times 10^{3} \mathrm{~kg}$-VS, equivalent to $75.56 \times 10^{3} \mathrm{~kg}-\mathrm{dw}$, was needed for a power generation of $1 \mathrm{MW}\left(1 \times 10^{6} \mathrm{watt}\right)$. Moisture content of 
grass was $78.14 \%$, therefore the wet weight $(\mathrm{ww})$ of grass required were $96.72 \times 10^{3} \mathrm{~kg}$. Results implied that in 87 days of fermentation time, 96.72 tons of grass or 405.77 ton of grass/year were sufficient to establish $1 \mathrm{MW}$ biomass power plant. The amount of cow dung was estimated in the same manner and 135.26 ton of cow dung was required to co-digest with 405.77 ton of grass to establish a $1 \mathrm{MW}$ biomass power plant. Since the production rate of grass in Thailand were average 375 tons/hectares/year (Department of Alternative Energy Development and Efficiency, Ministry of Energy, Thailand), therefore, the total area to grow grass for $1 \mathrm{MW}$ biomass power plant would be 1.08 hectares/year. However, it is worth noting that the amount of energy is depending on the concentration and quality of the gas and how the energy in methane is used.

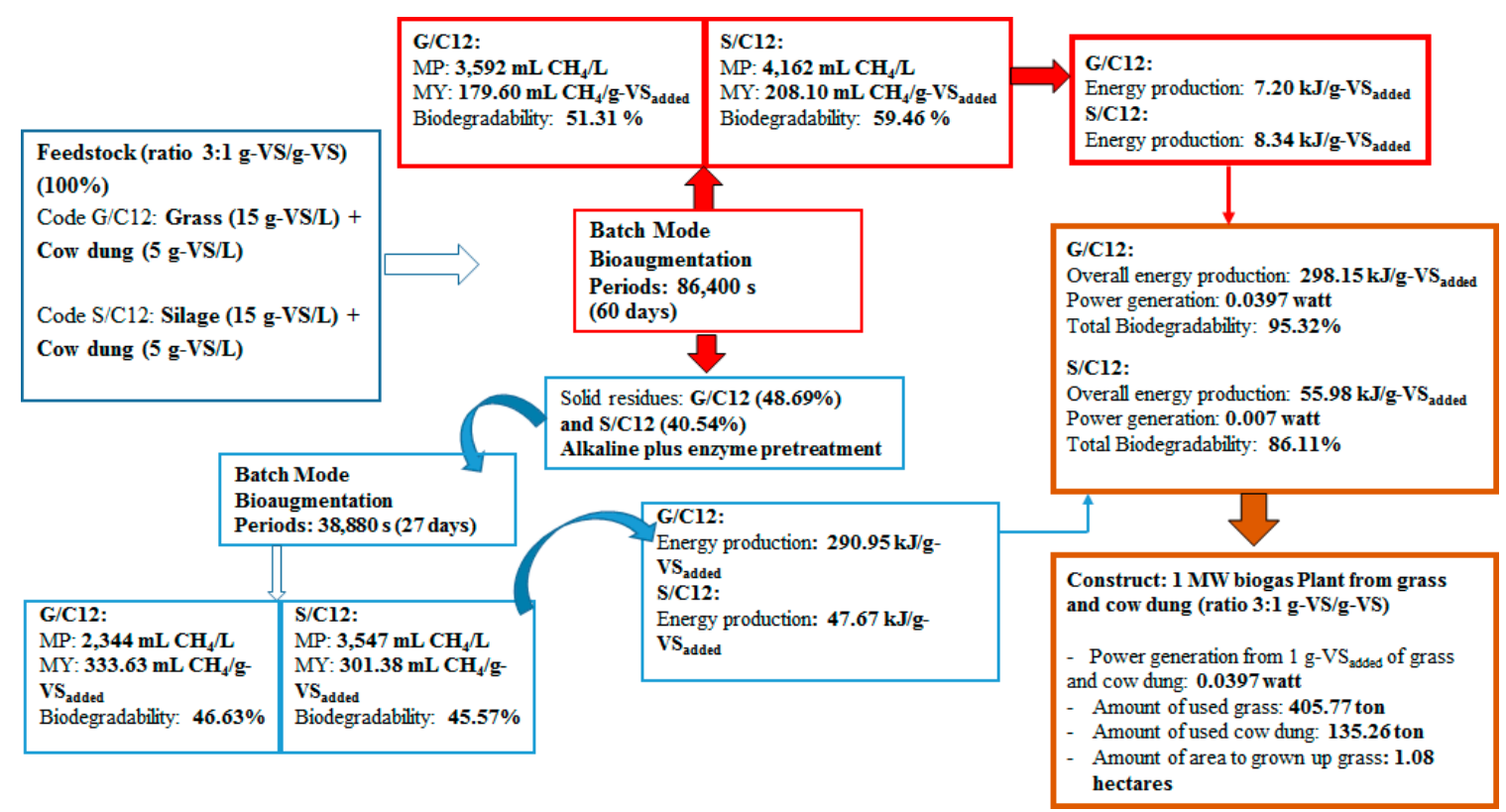

Figure 7. Energy production, power generation, biodegradation efficiency and the amount of grass and cow dung for constructing $1 \mathrm{MW}$ biogas from co-digestion of grass with cow dung at the mixing ratio of 3:1. G/C12: Co-digestion of grass with cow dung at the ratio of 3:1 g-VS/g-VS, S/C12: Co-digestion of silage with cow dung at the ratio of 3:1 g-VS/g-VS, MP: Methane production $\left(\mathrm{mL} \mathrm{CH}_{4} / \mathrm{L}\right)$; MY: Methane yield ( $\left.\mathrm{mL} \mathrm{CH}_{4} / \mathrm{g}-\mathrm{VS}_{\text {added }}\right)$.

\section{Materials and Methods}

\subsection{Substrates and Inoculum}

Napier grass was harvested from a field in Khon Kaen, Thailand. Silage was prepared by packing a grass in tightly closed containers, incubated at room temperature $\left(30 \pm 2{ }^{\circ} \mathrm{C}\right)$ for two weeks (self-fermentation). Both substrates were stored at $-20^{\circ} \mathrm{C}$. Before usage as a substrate, they were thawed at room temperature, chopped with knife and blend to a particle size of $0.5-1.0 \mathrm{~cm}$ in length by a household blender. Fresh cow dung slurry was obtained from a farm in Faculty of Agriculture, Khon Kaen University, Khon Kaen, Thailand and kept at $4{ }^{\circ} \mathrm{C}$ before used. The characteristics of grass, silage and cow dung are tabulated in Table 7.

Anaerobic sludge used as the inoculum for methane production was obtained from biogas plant of SF Khon Kaen Co., Ltd. (Amphoe Mueang Khon Kaen, Khon Kaen province, Thailand). The biogas plant produces methane from co-digestion of silage with chicken manure. Before it was directly used as the seed cultures, the sludge was fed with $10 \mathrm{~g} / \mathrm{L}$ glucose, incubated at room temperature $\left(30 \pm 2{ }^{\circ} \mathrm{C}\right)$. The fermentation was last for two weeks. After no biogas production was observed for one week, the seed culture was thoroughly mixed and filtered through a thin layer cloth. This was carried out to 
ensure the removal of easily degradable organic. The characteristics of the inoculum are presented in Table 7.

Table 7. Characteristics of grass, silage, cow dung, and anaerobic sludge.

\begin{tabular}{ccccc}
\hline Characteristic & Grass & Silage & Cow Dung & Anaerobic Sludge \\
\hline Total solid (TS) & $0.28^{\mathrm{a}}$ & $0.42^{\mathrm{a}}$ & $0.26^{\mathrm{a}}$ & $0.07^{\mathrm{a}}$ \\
Volatile solid (VS) & $0.25^{\mathrm{a}}$ & $0.38^{\mathrm{a}}$ & $0.20^{\mathrm{a}}$ & $0.04^{\mathrm{a}}$ \\
Moisture (\%) & 78.14 & 70.65 & 79.58 & 93.49 \\
pH & 5.58 & 3.84 & 8.28 & 7.89 \\
Ash (\%) & 3.31 & 3.36 & 5.35 & 2.97 \\
Cellulose (\%) & 29.48 & 31.95 & 24.49 & $\mathrm{ND}$ \\
Hemicellulose (\%) & 17.32 & 19.93 & 26.62 & $\mathrm{ND}$ \\
Lignin (\%) & 30.23 & 32.22 & 25.73 & $\mathrm{ND}$ \\
Carbon (\%) & 45.36 & 43.18 & 37.64 & $\mathrm{ND}$ \\
Nitrogen (\%) & 0.78 & 0.92 & 1.81 & ND \\
C/N & 58.15 & 46.93 & 20.80 & \\
\hline
\end{tabular}

ND: not determined, ${ }^{a}$ : unit in g/g-dry weight, All measurements were done in triplicates.

\subsection{Co-Digestion of Grass and Silage with Cow Dung}

An anaerobic co-digestion of grass with cow dung and silage with cow dung for methane production were examined at various mixing ratios of 1:1, 2:1, 3:1, 4:1, 5:1 and 6:1 (g-VS/g-VS). Each of the mixing ratios was achieved by fixing the cow dung concentration at $10 \mathrm{~g}-\mathrm{VS} / \mathrm{L}$ and varying grass or silage concentration in the ranges of 10-60 g-VS/L (Table 1). For bioaugmentation treatment, $10 \mathrm{~g}-\mathrm{VS} / \mathrm{L}$ of anaerobic sludge was added to the fermentation. A modified basic anaerobic (BA) medium with the anaerobic sludge was used as the control. The modified $\mathrm{BA}$ medium was contained (all in $\mathrm{g} / \mathrm{L}$ ); $100 \mathrm{NH}_{4} \mathrm{Cl}, 10 \mathrm{NaCl}, 20 \mathrm{MgCl}_{2} \cdot 6 \mathrm{H}_{2} \mathrm{O}, 5 \mathrm{CaCl}_{2} \cdot 5 \mathrm{H}_{2} \mathrm{O}, 200 \mathrm{~K}_{2} \mathrm{HPO}_{4} \cdot 3 \mathrm{H}_{2} \mathrm{O}, 52 \mathrm{NaHCO}_{3}, 2 \mathrm{FeCl}_{2} \cdot 4 \mathrm{H}_{2} \mathrm{O}$, $0.05 \mathrm{H}_{3} \mathrm{BO}_{3}, 0.05 \mathrm{ZnCl}_{2}, 0.038 \mathrm{CuCl}_{2} \cdot 2 \mathrm{H}_{2} \mathrm{O}, 0.05 \mathrm{MnCl}_{2} \cdot 4 \mathrm{H}_{2} \mathrm{O}, 0.05\left(\mathrm{NH}_{4}\right)_{6} \mathrm{Mo}_{7} \mathrm{O}_{24} \cdot 4 \mathrm{H}_{2} \mathrm{O}, 0.05 \mathrm{AlCl}_{3}$, $0.05 \mathrm{CoCl}_{2} \cdot 6 \mathrm{H}_{2} \mathrm{O}, 0.092 \mathrm{NiCl}_{2} \cdot 6 \mathrm{H}_{2} \mathrm{O}, 0.5$ ethylenediaminetetraacetate, $1 \mathrm{ml}$ concentrated $\mathrm{HCl}$, $0.1 \mathrm{Na}_{2} \mathrm{SeO}_{3} \cdot 5 \mathrm{H}_{2} \mathrm{O}, 100$ Yeast extract [51]. For self-fermentation treatment, the fermentation was conducted without an addition of inocula.

\subsection{Pretreatment of Solid Residue Left over after Methane Fermentation}

Pretreatment methods of solid residue left over after methane fermentation at the optimum grass with cow dung ratio and silage with cow dung ratio were grinding, alkaline, enzyme, grinding plus enzyme and alkaline plus enzyme pretreatment. The grinding method was conducted using food blender to cut the solid residues to small pieces and then sieved through $2 \mathrm{~mm}$ mesh. The alkaline pretreatment method was conducted in $500 \mathrm{~mL}$ glass bottles using a diluted sodium hydroxide solution $(2 \%(w / v) \mathrm{NaOH})$ at the ratio of solid residues to $\mathrm{NaOH}$ solution of 1:10 $(w / v)$. The mixture was autoclaved at $121^{\circ} \mathrm{C}$ for $60 \mathrm{~min}$ and left cooled at room temperature before filtered through a thin layer cloth. The solid fraction was collected and washed with distilled water until $\mathrm{pH} 7$ was achieved and dried at $60^{\circ} \mathrm{C}$ in a hot air oven for $24 \mathrm{~h}$ [52]. An enzymatic pretreatment was conducted using a commercially available Cellic ${ }^{\circledR}$ CTec2 (Novozyme), a cellulase cocktail with an activity of 193 filter paper unit (FPU)/mL. The enzymatic hydrolysis was conducted at an enzyme dose of $30 \mathrm{FPU} / \mathrm{g}$ dry matter in $0.05 \mathrm{mM}$ sodium citrate buffer $\mathrm{pH} 5.0$ [53]. Incubation was carried out at $50{ }^{\circ} \mathrm{C}, 150 \mathrm{rpm}$ for $72 \mathrm{~h}$. After the end of incubation process, the hydrolysate and solid residue were used as a substrate to produce methane. For a combined pretreatment, the solid residues obtained after grinding and alkaline pretreatment were further hydrolyzed by enzyme under the conditions described above.

\subsection{Methane Production}

Co-digestion of grass with cow dung and silage with cow dung for methane fermentation was conducted in $120 \mathrm{~mL}$ serum bottles with a working volume of $70 \mathrm{~mL}$. A modified BA medium was 
supplied to each bottle for making up a working volume to $70 \mathrm{~mL}$. For a methane production from the solid residue, the fermentations were conducted in $60 \mathrm{~mL}$ serum bottles with a working volume of $35 \mathrm{~mL}$. The concentration of pretreated solid residue of 1.70 and $5.59 \mathrm{~g}$-VS/L from co-digestion of grass with cow dung and silage with cow dung, respectively, were used to produce methane. A $10 \mathrm{~g}-\mathrm{VS} / \mathrm{L}$ of anaerobic sludge was used as inoculum. A modified BA medium was supplied to each bottle for making up a working volume to $35 \mathrm{~mL}$. Untreated solid residue with the anaerobic sludge was used as the control. The initial $\mathrm{pH}$ was adjusted to 7.5 by $5 \mathrm{M} \mathrm{HCl}$ or $5 \mathrm{M} \mathrm{NaOH}$. After capping with rubber stoppers and aluminum caps, a headspace in serum bottles was purged with nitrogen gas for $10 \mathrm{~min}$ to ensure anaerobic conditions. All experiment conditions were performed in triplicates. The experiments were carried out at the room temperature $\left(30 \pm 2{ }^{\circ} \mathrm{C}\right)$ on a continuous orbital shaker at $150 \mathrm{rpm}$. Biogas was measured during fermentation. The experiment that gave the highest methane production was kept for analyzed a microbial community by PCR-DGGE.

\subsection{Analytical Methods}

Total solid (TS), VS, moisture, ash, carbon, nitrogen were determined using standard methods [54]. Lignin, cellulose and hemicellulose were determined followed the method of Sluiter et al. (2008) [55]. The $\mathrm{pH}$ was measured by a $\mathrm{pH} 500 \mathrm{pH} / \mathrm{mV} / \mathrm{TEMP}$ meter. A volume of biogas was measured using wetted glass syringes [56]. The biogas compositions were determined by gas chromatography (Shimadzu GC-14, Kyoto, Japan) equipped with a thermal conductivity detector (TCD). The operating conditions were as follows: the carrier gas was helium under a pressure of $109.5 \mathrm{kPa}$ and a flow rate of $25 \mathrm{~mL} / \mathrm{min}$, injector temperature of $130{ }^{\circ} \mathrm{C}$, detector temperature of $140{ }^{\circ} \mathrm{C}$ and column temperature of $120^{\circ} \mathrm{C}$.

The structure of grass and silage before and after methane fermentation process were analyzed by SEM. Briefly, specimens were fixed in $2.5 \%$ glutaraldehyde and post fixed in $0.1 \mathrm{M}$ phosphate buffer (pH 7.2) for $2 \mathrm{~h}$. Next, fixed specimens were dehydrated through a 30, 50, 70 and $95 \%$ ethanol series for $10 \mathrm{~min}$ each and $100 \%$ ethanol for $5 \mathrm{~min}$. Finally, pieces were passed to absolute ethanol at the room temperature $\left(25^{\circ} \mathrm{C}\right)$; critical point dried and sputter coated with gold. Observations were made on a SEM (JEOL, Model JSM-5410LV, Akishima, Japan).

The structure of changes in untreated and pre-treated solid residues of co-digestion of grass with cow dung and silage with cow dung were analyzed by FTIR (Perkin Elmer Sdn Bhd, Selangor, Malaysia) using the potassium bromide ( $\mathrm{KBr}$ ) method. A preparation of sample was conducted by grinding solid residues and mixed with $\mathrm{KBr}$ at a ratio of 1:100 and then pressed to a pellet (KBr pellet). The pellet was passed into a disk for FTIR measurement. The spectra were recorded with 64 scans in the frequency range of $400-4000 / \mathrm{cm}$ with a resolution of $4.0 / \mathrm{cm}$.

The fermentation broth and sediment from the experiment that gave the highest MP was collected to be analyzed for the microbial community in the fermentation system i.e., in the liquid, solid residues as well as the attached on the surface). Samples were centrifuged at 10,000 rpm for $5 \mathrm{~min}$ in order to precipitate the suspended microbes. The cell pellets were collected and kept in $50 \%$ sterile glycerol at $-20^{\circ} \mathrm{C}$ prior to microbial community analysis [7] by PCR-DGGE following the method of Kongjan et al. (2011) [57]. Most of the bands were excised from the gel and re-amplified. After re-amplification, PCR products were purified and sequenced by Macrogen Inc. (Seoul, Korea). Closest matches for partial 16S rRNA gene sequences were identified by database searches in GeneBank using BLAST [58]. The modified Gompertz equation was applied to determine $\mathrm{MP}\left(\mathrm{mL} \mathrm{CH} \mathrm{CH}_{4} / \mathrm{L}\right)$, $\mathrm{Rm}\left(\mathrm{mL} \mathrm{CH}_{4} /(\mathrm{L} \cdot \mathrm{h})\right)$ and lag phase (h) [59].

Energy production was calculated as described by Reungsang et al. (2012) [60]. An energy production from methane $(\mathrm{kJ} / \mathrm{g}$-VS added $)$ was calculated by multiplying MY $\left(\mathrm{mL} \mathrm{CH}_{4} / \mathrm{g}\right.$-VS) with relative density of methane $\left(0.72 \mathrm{mg} \mathrm{CH}_{4} / \mathrm{mL}^{-\mathrm{CH}_{4}}\right)$ and the heating values of methane $\left(55.6 \mathrm{~J} / \mathrm{mg}^{-} \mathrm{CH}_{4}\right)[61]$. 
The power generation by a co-digestion of grass with cow dung and silage with cow dung was calculated as the following:

Power $($ watt $)=$ Overall energy production $(\mathrm{J}) /$ overall fermentation time $(\mathrm{s})$

\section{Conclusions}

Bioaugmentation technique is a promising approach for a methane production from a co-digestion of grass with cow dung and silage with cow dung. A co-digestion of grass with cow dung and silage with cow dung at the mixing ratio of 3:1 (g-VS grass or silage/g-VS of cow dung) gave the maximum MY of 179.59 and $208.11 \mathrm{~mL} \mathrm{CH}_{4} / \mathrm{g}-\mathrm{VS}_{\text {added }}$, respectively. The maximum energy yield of 7.20 and $8.34 \mathrm{~kJ} / \mathrm{g}$-VS were obtained from a co-digestion of grass with cow dung and silage with cow dung, respectively. Bioaugmentation of anaerobic sludge caused greater changes in bacterial community structure as well as archaea community structure. Solid residues left over after a methane production from a co-digestion of grass with cow dung and silage with cow dung at the optimum conditions of 3:1 pretreated by an alkaline plus enzyme pretreatment enhanced a methane production from grass with cow dung and silage with cow dung. The maximum MY from solid residues of grass with cow dung and silage with cow dung pretreated by alkaline plus enzyme method were 333.63 and $301.38 \mathrm{~mL}$ $\mathrm{CH}_{4} / \mathrm{g}$-VS $\mathrm{Vdded}_{\text {, }}$ respectively. The overall energy production from a co-digestion of grass with cow dung plus pretreated solid residues and silage with cow dung plus pretreated solid residues were 298.15 and $55.98 \mathrm{~kJ} / \mathrm{g}-\mathrm{VS}_{\text {added}}$, respectively.

Acknowledgments: This study was supported by Energy Conservation Promotion Fund, Energy Policy and Planning Office, Ministry of Energy, Thailand. The Ph.D. scholarship for W. Prapinagsorn was kindly provided by Uttaradit Rajabhat University. Research fund were provided by Research Group for Development of Microbial Hydrogen Production Process from Biomass-Khon Kaen University and TRF Senior Research Scholar (Grant No. RTA5980004).

Author Contributions: Alissara Reungsang conceived, designed the experiments, corrected and revised the manuscript; Wipa Prapinagsorn performed the experiments; Wipa Prapinagsorn and Sureewan Sittijunda analyzed the data; Wipa Prapinagsorn and Sureewan Sittijunda drafted the manuscript. All the authors have read, corrected, and approved the manuscript.

Conflicts of Interest: The authors declare no conflict of interest.

\section{References}

1. Chandra, R.; Takeuchi, H.; Hasegawa, T. Methane production from lignocellulosic agricultural crop wastes: A review in context to second generation of biofuel production. Renew. Sustain. Energy Rev. 2012, 16, 1462-1476. [CrossRef]

2. Moset, V.; Al-zohairi, N.; Møller, H.B. The impact of inoculum source, inoculum to substrate ratio and sample preservation on methane potential from different substrates. Biomass Bioenergy 2015, 83, 474-482. [CrossRef]

3. Saravanane, R.; Murthy, D.V.S.; Krishnaiah, K. Treatment of anti-osmotic drug based pharmaceutical effluent in an upflow anaerobic fluidized bed system. Waste Manag. 2001, 21, 563-568. [CrossRef]

4. Cater, M.; Fanedl, L.; Malovrh, S.; Logar, R.M. Biogas production from brewery spent grain enhanced by bioaugmentation with hydrolytic anaerobic bacteria. Bioresour. Technol. 2015, 186, 261-269. [CrossRef] [PubMed]

5. Kim, J.; Kang, C.M. Increased anaerobic production of methane by co-digestion of sludge with microalgal biomass and food waste leachate. Bioresour. Technol. 2015, 189, 409-412. [CrossRef] [PubMed]

6. Dalkılıc, K.; Ugurlu, A. Biogas production from chicken manure at different organic loading rates in a mesophilic-thermopilic two stage anaerobic system. J. Biosci. Bioeng. 2015, 120, 315-322. [CrossRef] [PubMed]

7. Nualsri, C.; Reungsanga, A.; Plangklang, P. Biochemical hydrogen and methane potential of sugarcane syrup using a two-stage anaerobic fermentation process. Ind. Crops Prod. 2016, 82, 88-99. [CrossRef] 
8. Naran, E.; Toor, U.A.; Kim, D.J. Effect of pretreatment and anaerobic co-digestion of food waste and waste activated sludge on stabilization and methane production. Int. Biodeterior. Biodegrad. 2016, 113, 17-21. [CrossRef]

9. Hassan, M.; Ding, W.; Shi, Z.; Zhao, S. Methane enhancement through co-digestion of chicken manure and thermo-oxidative cleaved wheat straw with waste activated sludge: A C/N optimization case. Bioresour. Technol. 2016, 211, 534-541. [CrossRef] [PubMed]

10. Xie, X.M.; Zhang, X.Q.; Dong, Z.X.; Guo, H.R. Dynamic changes of lignin contents of MT-1 elephant grass and its closely related cultivars. Biomass Bioenergy 2011, 35, 1732-1738. [CrossRef]

11. Menegol, D.; Scholl, A.L.; Fontana, R.C.; Dillon, A.J.P.; Camassola, M. Increased release of fermentable sugars from elephant grass by enzymatic hydrolysis in the presence of surfactants. Energy Convers. Manag. 2014, 88, 1252-1256. [CrossRef]

12. Sawasdee, V.; Pisutpaisal, N. Feasibility of Biogas Production from Napier Grass. Energy Procedia 2014, 61, 1229-1233. [CrossRef]

13. Lu, Q.L.; Tang, L.R.; Wang, S.; Huang, B.; Chen, Y.D.; Chen, X.R. An investigation on the characteristics of cellulose nanocrystals from Pennisetum sinese. Biomass Bioenergy 2014, 70, 267-272. [CrossRef]

14. Dussadee, N.; Reansuwan, K.; Ramaraj, R. Potential development of compressed bio-methane gas production from pig farms and elephant grass silage for transportation in Thailand. Bioresour. Technol. 2014, 155, 438-441. [CrossRef] [PubMed]

15. Pu, Y.; Zhang, D.; Singh, P.M.; Ragauskas, A.J. The new forestry biofuels sector. Biofuels Bioprod. Biorefin. 2008, 2, 58-73. [CrossRef]

16. Saha, B.C. Hemicellulose bioconversion. Microbiol. Biotechnol. 2003, 30, 279-326. [CrossRef] [PubMed]

17. Ren, N.; Wang, A.; Cao, G.; Xu, J.; Gao, L. Bioconversion of lignocellulosic biomass to hydrogen: Potential and challenges. Biotechnol. Adv. 2009, 27, 1051-1060. [CrossRef] [PubMed]

18. Strezov, V.; Evans, T.J.; Hayman, C. Thermal conversion of elephant grass (Pennisetum Purpureum Schum) to bio-gas, bio-oil and charcoal. Bioresour. Technol. 2008, 99, 8394-8399. [CrossRef] [PubMed]

19. Mital, K.M. Biogas Systems: Principles and Applications; New Age International (P) Limited: Delhi, India, 1996.

20. Callaghan, F.J.; Wase, D.A.J.; Thayanity, K.; Forster, C.F. Continuous co-digestion of cattle slurry with fruit and vegetable wastes and chicken manure. Biomass Bioenergy 2002, 22, 71-77. [CrossRef]

21. Li, Y.; Li, Y.; Zhang, D.; Li, G.; Lu, J.; Li, S. Solid state anaerobic co-digestion of tomato residues with dairy manure and corn stover for biogas production. Bioresour. Technol. 2016, 217, 50-55. [CrossRef] [PubMed]

22. Li, W. High-Solid Anaerobic Co-digestion of Horse Manure and Grass in batch and semi- continuous Systems. Energy Fuel 2016, 30, 6419-6424. [CrossRef]

23. Wall, D.M.; Allen, E.; Straccialini, B.; Kiely, P.O.; Murphy, J.D. Optimisation of digester performance with increasing organic loading rate for mono- and co-digestion of grass silage and dairy slurry. Bioresour. Technol. 2014, 173, 422-428. [CrossRef] [PubMed]

24. Nissila, M.E.; Lay, C.; Puhakka, J. Dark fermentative hydrogen production from lignocellulosic hydrolyzates. A review. Biomass Bioenergy 2014, 67, 145-159. [CrossRef]

25. Yang, B.; Wyman, C.E. Pretreatment: The key to unlocking low cost cellulosic ethanol. Biofuels Bioprod. Biorefin. 2008, 2, 26-40. [CrossRef]

26. Parkin, G.F.; Owen, W.F. Fundamentals of anaerobic digestion of wastewater sludges. J. Environ. Eng. 1986, 112, 867-920. [CrossRef]

27. Brown, D.; Li, Y. Solid state anaerobic co-digestion of yard waste and food waste for biogas production. Bioresour. Technol. 2013, 127, 275-280. [CrossRef] [PubMed]

28. Li, Y.; Zhang, R.H.; Liu, X.Y.; Chen, C.; Xiao, X.; Feng, L.; He, Y.F.; Liu, G.Q. Evaluating methane production from anaerobic mono- and co-digestion of kitchen waste, corn stover, and chicken manure. Energy Fuel 2013, 27, 2085-2091. [CrossRef]

29. Xie, S.; Lawlor, P.G.; Frost, J.P.; Hu, Z.; Zhan, X. Effect of pig manure to grass silage ratio on methane production in batch anaerobic co-digestion of concentrated pig manure and grass silage. Bioresour. Technol. 2011, 102, 5728-5733. [CrossRef] [PubMed]

30. Yahaya, M.S.; Kimura, A.; Harai, J.; Nguyen, H.V.; Kawai, M.; Takahashi, J.; Matsuoka, S. Evaluation of structural carbohydrates losses and digestibility in Alfalfa and Orchard grass during ensiling 1. Asian-Aust. J. Anim. Sci. 2001, 14, 1701-1704. [CrossRef] 
31. McDonald, P.; Henderson, A.R.; Heron, S.J.E. Principle of Ensilage. In The Biochemistry of Silage, 2nd ed.; Chalcombe Publications: Southampton, UK, 1991.

32. Wu, G.; Healy, M.G.; Zhan, X. Effect of the solid content on anaerobic digestion of meat and bone meal. Bioresour. Technol. 2009, 100, 4326-4331. [CrossRef] [PubMed]

33. Yokoi, H.; Saitsu, A.; Uchida, H.; Hirose, J.; Hayashi, S.; Takasaki, Y. Microbial hydrogen production from sweet potato starch residue. J. Biosci. Bioeng. 2001, 91, 58-63. [CrossRef]

34. Lehtomaki, A.; Huttunen, S.; Rintala, J.A. Laboratory investigations on co-digestion of energy crops and crop residues with cow manure formethane production: Effect of crop to manure ratio. Resour. Conserv. Recycl. 2007, 51, 591-609. [CrossRef]

35. Canam, T.; Town, J.; Iroba, K.; Tabil, L.; Dumonceaux, T. Pretreatment of Lignocellulosic Biomass Using Microorganisms: Approaches, Advantages, and Limitations. In Sustainable Degradation of Lignocellulosic Biomass Techniques, Applications and Commercialization; Chandel, A., Ed.; InTech: Rijeka, Croatia, 2013.

36. Zhai, N.; Zhang, T.; Yin, D.; Yang, G.; Wang, X.; Ren, G.; Feng, Y. Effect of initial pH on anaerobic co-digestion of kitchen waste and cow manure. Waste Manag. 2015, 38, 126-131. [CrossRef] [PubMed]

37. Zheng, Z.; Liu, J.; Yuan, X.; Wang, X.; Zhu, W.; Yang, F.; Cui, Z. Effect of dairy manure to switchgrass co-digestion ratio on methane production and the bacterial community in batch anaerobic digestion. Appl. Energy 2015, 151, 249-257. [CrossRef]

38. Cata Saady, N.M. Homoacetogenesis during hydrogen production by mixed cultures dark fermentation: Unresolved challenge. Int. J. Hydrogen Energy 2013, 38, 13172-13191. [CrossRef]

39. Saengkerdsub, S.; Kim, W.K.; Anderson, R.C.; Nisbet, D.J.; Ricke, S.C. Effects of nitrocompounds and feedstuffs on in vitro methane production in chicken cecal contents and rumen fluid. Anaerobe 2006, 12, 85-92. [CrossRef] [PubMed]

40. Kim, J.; Jung, H.; Lee, C. Shifts in bacterial and archaeal community structures during the batch biomethanation of Ulva biomass under mesophilic conditions. Bioresour. Technol. 2014, 169, 502-509. [CrossRef] [PubMed]

41. Zhao, L.; Cao, G.L.; Wang, A.J.; Ren, H.Y.; Zhang, K.; Ren, N.Q. Consolidated bioprocessing performance of Thermoanaerobacterium thermosaccharolyticum M18 on fungal pretreated cornstalk for enhanced hydrogen production. Biotechnol. Biofuels 2014, 7, 178. [CrossRef] [PubMed]

42. Yang, X.W.; Zeng, Y.L.; Ma, F.Y.; Zhang, X.Y.; Yu, H.B. Effect of biopretreatment on thermogravimetric and chemical characteristics of corn stover by different white-rot fungi. Bioresour. Technol. 2010, 101, 5475-5479. [CrossRef] [PubMed]

43. Fan, L.T.; Gharpuray, M.M.; Lee, Y.H. Cellulose hydrolysis. In Biotechnology Monographs; Springer: Berlin, Germany, 1987.

44. Salehian, P.; Karimi, K. Alkali pretreatment for improvement of biogas and ethanol production from different waste parts of pine tree. Ind. Eng. Chem. Res. 2013, 52, 972-978. [CrossRef]

45. Zheng, Y.; Zhao, J.; Xu, F.; Li, Y. Pretreatment of lignocellulosic biomass for enhanced biogas production. Prog. Energy Combust. 2014, 42, 35-53. [CrossRef]

46. Lo, Y.C.; Su, Y.C.; Cheng, C.L.; Chang, J.S. Biohydrogen production from pure and natural lignocellulosic feedstock with chemical pretreatment and bacterial hydrolysis. Int. J. Hydrogen Energy 2011, 36, 13955-13963. [CrossRef]

47. Zhang, W.; Yi, Z.L.; Huang, J.F.; Li, F.C.; Hao, B.; Li, M.; Hong, S.F.; Lv, Y.Z.; Sun, W.; Ragauskas, A.; et al. Three lignocellulose features that distinctively affect biomass enzymatic digestibility under $\mathrm{NaOH}$ and $\mathrm{H}_{2} \mathrm{SO}_{4}$ pretreatments in Miscanthus. Bioresour. Technol. 2013, 130, 30-37. [CrossRef] [PubMed]

48. Michalska, K.; Bizukoj, M.; Ledakowicz, S. Pretreatment of energy crops with sodium hydroxide and cellulolytic enzymes to increase biogas production. Biomass Bioenergy 2015, 80, 213-221. [CrossRef]

49. Lin, R.; Cheng, J.; Song, W.; Ding, L.; Xie, B.; Zhou, J.; Cen, K. Characterisation of water hyacinth with microwave-heated alkali pretreatment for enhanced enzymatic digestibility and hydrogen/methane fermentation. Bioresour. Technol. 2015, 182, 1-7. [CrossRef] [PubMed]

50. Michalska, K.; Ledakowicz, S. Alkali pre-treatment of Sorghum Moench for biogas production. Chem. Pap. 2013, 67, 1130-1137. [CrossRef]

51. Fangkum, A.; Reungsang, A. Biohydrogen production from mixed xylose/arabinose at thermophilic temperature by anaerobic mixed cultures in elephant dung. Int. J. Hydrogen Energy 2011, 36, 13928-13938. [CrossRef] 
52. Cao, W.; Sun, C.; Liu, R.; Yin, R.; Wu, X. Comparison of the effects of five pretreatment methods on enhancing the enzymatic digestibility and ethanol production from sweet sorghum bagasse. Bioresour. Technol. 2012, 111, 215-221. [CrossRef] [PubMed]

53. Ludwig, D.; Michael, B.; Hirth, T.; Rupp, S.; Zibek, S. High Solids Enzymatic Hydrolysis of Pretreated Lignocellulosic Materials with a Powerful Stirrer Concept. Appl. Biochem. Biotechnol. 2014, 172, 1699-1713. [CrossRef] [PubMed]

54. APHA. Standard Methods for Examination of Water and Wastewater, 18th ed.; American Public Health Association: Washington, DC, USA, 1995.

55. Sluiter, A.; Hames, B.; Ruiz, R.; Scarlata, C.; Sluiter, J.; Templeton, D.; Crocker, D. Determination of Structural Carbohydrates and Lignin in Biomass; Laboratory Analytical Procedure; National Renewable Energy Laboratory: Golden, CO, USA, 2008; pp. 1-18.

56. Owen, W.; Stuckey, C.; Healy, J.; Young, L.; McCarty, P. Bioassay for monitoring biochemical methane potential and anaerobic toxicity. Water Res. 1979, 13, 485-492. [CrossRef]

57. Kongjan, P.; O-Thong, S.; Angelidaki, I. Performance and microbial community analysis of two-stage process with extreme thermophilic hydrogen and thermopholic methane production from hydrolysate in UASB reactors. Bioresour. Technol. 2011, 102, 4028-4035. [CrossRef] [PubMed]

58. Altschul, S.F.; Madden, T.L.; Schaffer, A.A.; Zhang, J.; Zhang, Z.; Miller, W. Gapped BLAST and PSI-BLAST: A new generation of protein database search programs. Nucleic Acids Res. 1997, 25, 3389-3402. [CrossRef] [PubMed]

59. Zwietering, M.H.; Jongenburger, L.; Rombouts, F.M.; Van't, R.K. Modeling the bacterial growth curve. Appl. Environ. Microbiol. 1990, 64, 1878-1883.

60. Reungsang, A.; Pattra, S.; Sittijunda, S. Optimization of Key Factors Affecting Methane Production from Acidic Effluent Coming from the Sugarcane Juice Hydrogen Fermentation Process. Energies 2012, 5, 4746-4757. [CrossRef]

61. Sittijunda, S. Biogas Production from Hydrolysate Napier Grass by Co-Digestion with Slaughterhouse Wastewater using Anaerobic Mixed Cultures. KKU Res. J. 2015, 20, 323-336.

(C) 2017 by the authors. Licensee MDPI, Basel, Switzerland. This article is an open access article distributed under the terms and conditions of the Creative Commons Attribution (CC BY) license (http:/ / creativecommons.org/licenses/by/4.0/). 